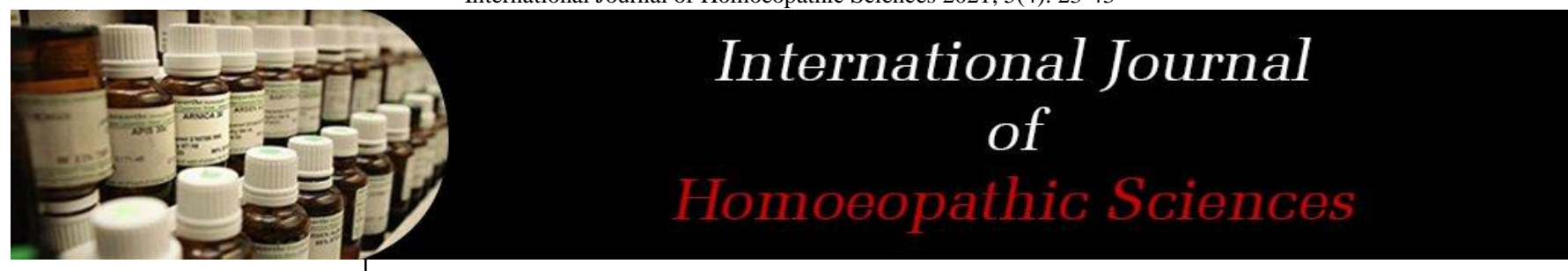

E-ISSN: 2616-4493 P-ISSN: 2616-4485 www.homoeopathicjournal.com IJHS 2021; 5(4): 23-43

Received: 23-05-2021

Accepted: 14-07-2021

Dr. Sinchan Das

Humanity Institute of Advanced Medical \& Cultural Research, J-40, Kamdahari, Banerjeepara, Kolkata, West Bengal, India

Priyankesh Mishra Humanity Institute of Advanced Medical \& Cultural Research, J-40, Kamdahari, Banerjeepara, Kolkata, West Bengal, India

Swastika Subba

Humanity Institute of

Advanced Medical \& Cultural Research, J-40, Kamdahari, Banerjeepara, Kolkata, West Bengal, India
Corresponding Author: Dr. Sinchan Das Humanity Institute of Advanced Medical \& Cultural Research, J-40, Kamdahari, Banerjeepara, Kolkata, West Bengal, India

\section{COVID-19, a manmade disaster, its treatment \& pharmacodynamics of indicated remedies}

\author{
Dr. Sinchan Das, Priyankesh Mishra and Swastika Subba
}

DOI: https://doi.org/10.33545/26164485.2021.v5.i4a.451

\begin{abstract}
Repeatedly history has been a proof that each time human have tried to manipulate nature, it has made humankind repent for each deed. The nature of epidemic and pandemic from the plague of Athens to the outbreak of COVID-19, all are the rewards of the greed, manipulation and hyper-individualistic mentality of the humans. All this faulty habits and ignorance of human being has made ACE-2 and TMPRSS-2 the major gateways for further infection and damage in our body. However, it interesting to noted that the main cause of COVID-19 that was been hiding behind ever since its prevalence was nonother than the oxidative stress followed by Natural Disasters and Genetic Causes. Despite of much advancement and enhancement in the field of science, technology and medicine, the hyperindividualistic complexes of the human beings makes them deny the fact. The modern civilised section of the society feels that there a pill for every ill while making them more and more drug depended. This has contributed the pharmaceuticals lords in introducing more and more manipulation. According to these pharmaceuticals lords the creation Vaccine, Antidote, Antiviral and Antibiotics is the major shield for saving the humankind, but is it so? If it is true than who should be answerable for all this increasing death rates around the world, aren't this Vaccine supposed to stop the prevalence of COVID-19 and other diseases. The Fact is the world today has become an open laboratory with millions of guinea pigs harbouring like a headless chickens.
\end{abstract}

Keywords: Yucatec maya, traditional medicine, plant use, herbalist

\section{Introduction}

Earth, a divine creation of universe; a planet having all sources of life and life preserving resources. A beautiful planet that is well-designed to maintain its integrity and existence. Among many other components of this nature, human beings are one component. Human beings, the self-declared lord or self-declared most intelligent species of this nature. Nature is a balanced state, where each and every components of her can live harmoniously, under a clearly defined principle. For nature, every component is of equal importance and they are inter-dependable to each other; any harm to any of them can lead to a serious gross disequilibrium and followed by an irreversible damage, irrespective of our acceptability or ignorance. Human beings are the most complex species, who are able to think, preserve and destroy; actually, being the delayed product of evolution, they are empowered to protect themselves from the usual natural insults and also to protect all other natural components in order to maintain natural equilibrium. To maintain this natural equilibrium, it is necessary to understand the natural principle and circumstances in an unbiased and thorough manner; that is why education is designed. This psychology of enquiry, is not developed by the mankind at all, it is the gift of nature. Every species have their own forms of enquiry and intelligence, human beings are not an exceptional one. Among the prides of mankind, development of 'Science' is the principal one.

Science is a subject which is designed to understand and explain the natural phenomena, with the help of a universal language, understandable to everyone. But now days, science has become an instrument of humanitarian complexes; where it is now used to design instruments which are able to damage the entire nature. The blessings now become the curse, the responsible factor of natural destruction. A subject which is designed to explain natural phenomena with the light of logic, now become the subject which can deny natural facts and events in a wondering manner. The style of human race is to ignore the actual facts where they must be guilty and blaming others to hide their own guilt. Human race is the responsible factor for all the environmental pollution and destructions. 
In this $21^{\text {st }}$ century, the world has faced a deadly monster, named CoVid-19. More than hundred years, since the outbreak of the Influenza pandemic of 1918, the world now seems to face this pandemic in larger extent. The outbreak of SARS-CoV-2 infection is spreading to every continent, affecting a large number of populations worldwide; forcing the mankind to close themselves within their houses and has compelled us to live with this deadly pathogen for perhaps a long time. Further, this particular pandemic is compelling the scientists and clinicians to re-analyze the faults and fallacies of the medical system in respect to these collapsing medical fraternities.

The histories of the pandemic and the introduction of new viruses are not new rather it's as old as the theatres of the earth's civilization. After each epidemic \& pandemic or any outbreaks a new virus emerges that have something in common from the virus that previously existed. So, can we say that viruses we discuss today are actually the new? Or the evolved or point/frame shift mutated virus? According to genetics, mutations are the root cause of the evolution; evolutions occur due to the changes in the environment. So, environment is the factor that is getting harmed by everyone day-by-day that led to new evolution or the environment in which these particular viruses reside. So, for the development of a disease, environment must play an important role. From the definition of health, given by World Health Organization (WHO), one can find three parameters in order to qualify health as a whole, which are-Psychological, Physical \& Social parameters; but in reality there is another missing but most important parameter, i.e. environmental factor. Environment or nature where all the natural components (microorganisms, plants, animals, humans) live in a harmonious manner in order to maintain proper harmony. For the maintenance of this natural harmony, equilibrium should be maintained between all the components of the nature. But, our humanitarian complex is drastically damaging this social equilibrium in a dangerous way. We all are running behind a virtual health by compromising the actual one.

Although after a long while, we have witnessed such a pandemic, which have become the cause of fear around the globe. But one can easily find that, we are residing in a diseased and drug-dependent era, where the entire world is submerged under the dump of several diseases. However, with the advancement in Medical technology, we have avoided many infectious diseases, but in exchange of several autoimmune and metabolic diseases. Regardless, CoVid-19 is a major health concern, as it is a rapidly growing infectious disease with serious as well as devastating outcomes, especially the ones who are susceptible to this disease. In this modern era, when we feel too much satisfied with our complexes and hyper-scientific fast lifestyle, a viral disease has collapsed all the systems in a drastic manner. Those continents which are declared as developed have become more affected by this deadly virus. There are numerous questions that gets arise during this pandemic----
- What is the cause of this infection susceptibility?

- Why this outbreak?

- What is the cause behind these death incidences?

- Why this left uncontrollable?

Function of ACE is to convert Angiotensin into Angiotensin-I, in order to raise the blood pressure to meet the metabolic need of the body. But the prolonged elevation is commonly diagnosed as the Hypertension. When ACE inhibitors or Angiotensin receptor blockers are administers in order to control the blood pressure, without giving a minimum emphasis on the cause responsible for the particular elevation \& the body becomes a victim of drugdependent pathology. In that time, our body starts to synthesize another homologous enzyme having the potential to exhibit anti-hypertensive properties. But, the actual cause behind the elevation still remains unchecked and additionally, body has become more damaged by the artificial chemical substance. As a result of this, after a considerable time, a series of additional manifestations starts to appear and serious multi-organ involvement is then encountered. By this means an individual has become a victim of drug-dependent pathology. In these conditions, the nature will identify that individual as a diseased individual. Hippocrates said, 'Nature is the best physician'; apart from being a best physician nature also has the potential to control all the natural diseases, with her own efficiency. Interrupting with this particular process, is nothing but contributing in complicating the mechanism more $\&$ more.

From the very beginning, we have been residing in that environment where viruses \& bacteria are all living in a harmonious manner. They are not at all interested in infecting anybody, until \& unless they get a suitable environment to reside. When your body becomes impure internally and running against the natural rule, nature will consider you as a diseased material and in that respect microorganisms are the natural scavengers. Infection of the virus must be associated with accumulation of impurities within the body, where they are present to clean up those impurities. In case of CoVID-19, the affinity of the SARS$\mathrm{CoV}-2$ is those individuals who possess a prior diseased environment, as they have over expression of ACE2 \& TMPRSS2. So, the targets are already diseased, that is why the site of infection for SARS-CoV-2 is those tissues which have higher expression of those materials. Therefore, SARS-CoV-2 is not a cause by any means; it is just a natural scavenger.

Although there are several evidences regarding the inappropriateness and adverse effects of the vaccines, but the scientific community is surprisingly endorse these vaccines in a strange manner. Adverse effects of vaccines are much higher than the beneficial effects of vaccine. In order to control infection, by targeting a microorganism and by ignoring the root cause of infections, they have damaged the organism in a serious manner, generation after generation. 


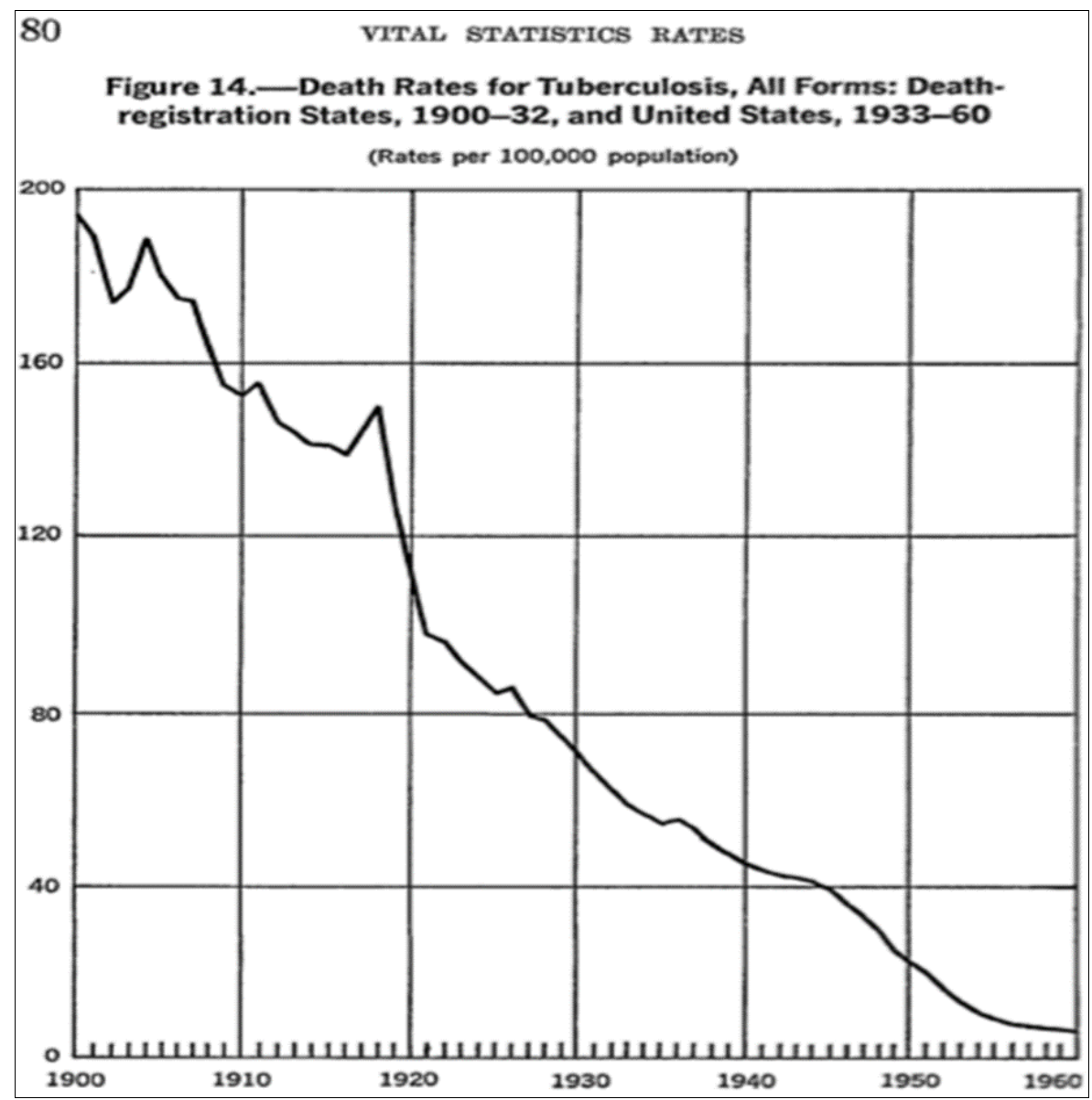

Fig 1: Vital statistics rates

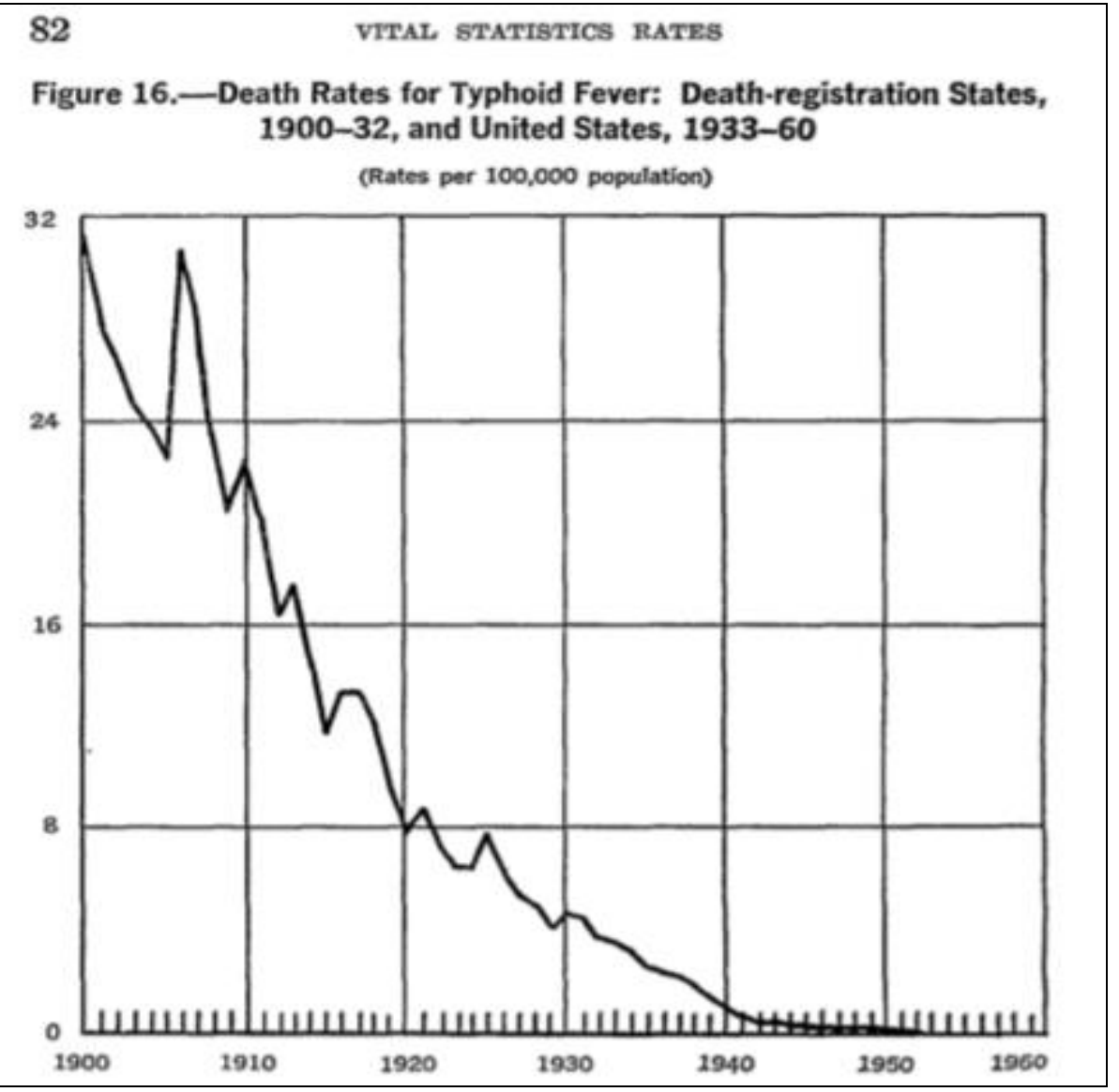

Fig 2: Vital statistics rates 


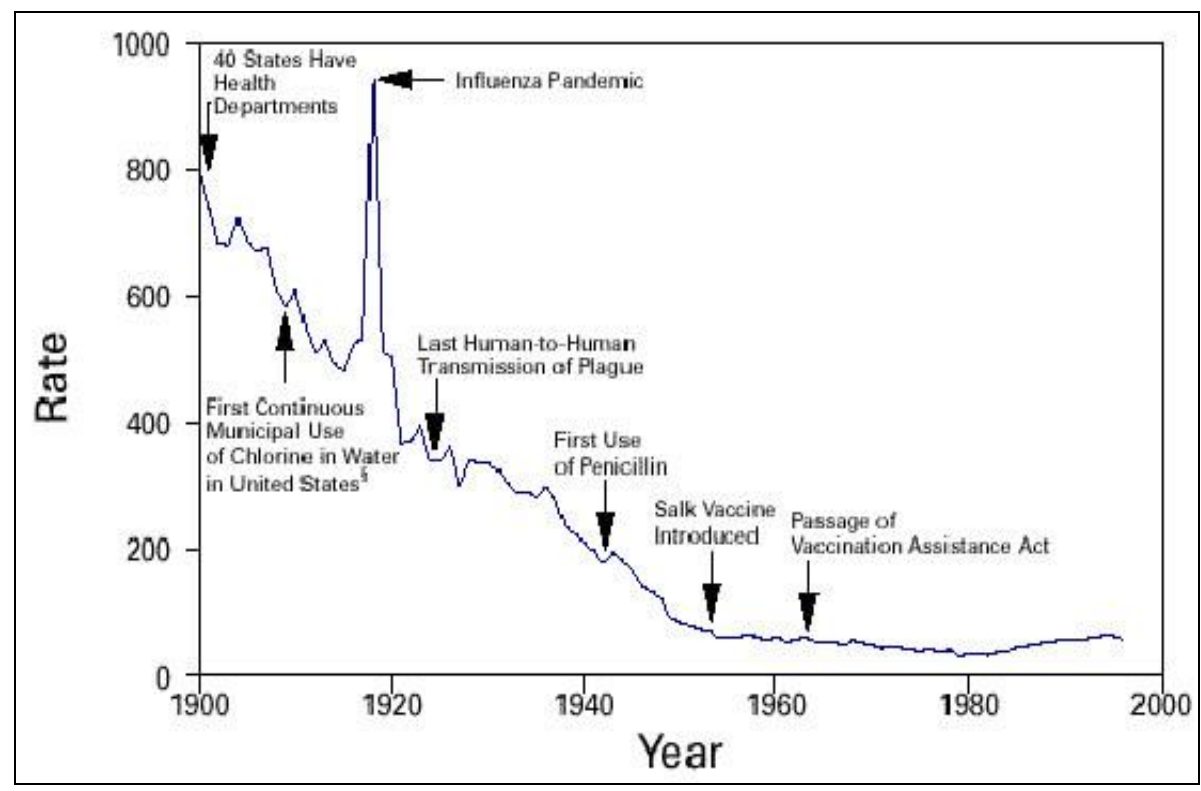

Fig 3: BCG (TB vaccine) was introduced in 1953, after TB had already declined

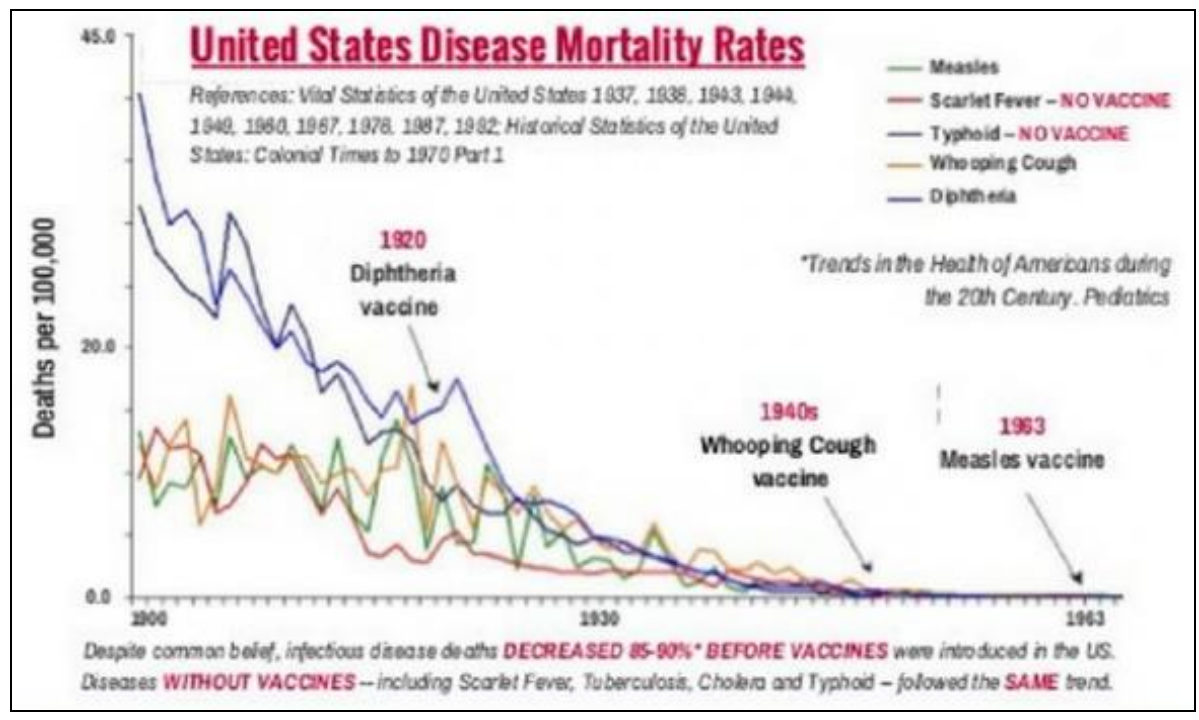

Fig 4: No widespread vaccination program for Typhoid but the disease still declined

The incidents, we are unable to understand or to explain, usually declared as 'accidents', 'miracles', 'happen by chance' etc., cannot permit us to allow those to consider as correct results just because of our biased mentality. This is nothing but the 'preference'; because preference is made on the basis of personal comfort, guided by the mentality to avoid risks, tendency to avoid controversies and to obtain results easily. This nature is nothing but the 'biasness'. Homoeopathy, Ayurveda these traditional systems of medicines are victims of this biased nature \& forcefully endorsed Allopathic system of medicine in our life. As our topic of study is 'mechanism of action of Homoeopathic medicines' I want to discuss about Homoeopathy in short. Homoeopathy is a system of medicine, based on a fixed principle i.e. 'similia similibus curenter' and following three fundamental guidelines, i.e. 1) minimum medicine, 2) minimum dose and 3) maximum similarity. Historically the concept of 'like cure likes' originated in time of the father of medicine Hippocrates. After long time, Dr. C.F.S. Hahnemann established this system of medicine with the name Homoeopathy. Before selecting a Homoeopathic remedy, it is of prime importance that we have to construct a perfect 'totality of symptoms', depending on which we have to select the particular indicated Homoeopathic remedy. We know that, every stimulus is capable of altering a particular state of health, altering in an unique manner and varying in intensity. From this point of view, Homoeopathy does not consider disease alone as a distinct pathological entity, rather a diseased person as a whole. In Homoeopathy, there are more than one medicine grouped under a single disease, but considering all the deviations of body and mind (totality of symptoms) carefully, they can find only one medicine indicated for the particular pathological state of a particular disease. For example, if we consider some cases of 'Arsenic poisoning', where many people think as Homoeopathy considers 'like cure likes', then one can prescribe the Homoeopathic Arsenicum album in every case of arsenic poisoning blindly and observing the inappropriate results they can easily able to declare that Homoeopathy is a pseudoscience or nothing but the placebo effect etc. But, by considering the symptomatology of arsenic poisoning, one can easily find there are different symptoms \& signs in different stages of arsenic poisoning. That is why in those different phases you have to prescribe 
different Homoeopathic medicines to obtain a desired result. Before considering these minutest deviations for medicinal selection, it is immaterial to declare any biased statement blindly.

Now, let us come to another point of discussion, i.e. 'mode of treatment'. The mode of treatment means the paths need to be followed to treat a pathological condition. Which path is ideal for treatment is intentionally made controversial and debatable also. Let us take a view on the possible routes of treatment procedures. Treatment can be done mainly with the help of drugs along with many other methods but the physicians readily avoid those methods in recent dates. The body is a self-manageable instrument, not a non-living instrument. The body has the capabilities to combat with the offending pathological stimuluses and agents spontaneously with its own instruments. Now the question arises, if body can combat with all insults spontaneously, then what is the utility to apply any medicinal substance and how? It is true that body is a self- manageable instrument, but every instrument has its limitation of work. To help the living instrument we have to assist the body with our medicines not to interrupt its spontaneous action with artificial chemical substances.

Another point we have to discuss, i.e. the placebo effects. Discussion of the 'placebo effect' is important, because many people consider homoeopathic medicinal effects as placebo effects. Placebo is a non-medicinal substance does not possess any medicinal property. These substances are used to treat patients psychologically or to give mental satisfaction to the patients, where true pathological deviations are absent. But before considering a case for placebo, one has to be sanguine about the nature of the case. Placebo can treat any sensation of discomfort not originating pathologically or not deep-seated; but natural diseases, having pathological findings, cannot be treated with placebo. After considering remarkable changes in the pathological data, even in those cases where modern medicine failed to act, considering Homoeopathic medicines as placebo is nothing but the proof of their biasness, faulty way of thought and half- hearted knowledge. We know that for the development of a pathological condition, there is a major role of our thought, rather better to say maximum of the role played by our thought, but its exact mechanism is still not known. In these cases placebo or non-medicinal substances can help us to correct his or her mental alteration to some extent, which may uncover their physical alterations produced by the influence of those improper thoughts.

Origin of the Pandemics: CoVID-19 is the largest pandemic of the human civilization, which travels considerably a long distance, and most efficiently affects a larger number of populations with a notable virulence. The rate of global involvement in CoVID-19 is surprising \& horrible because it is relatively impossible to maintain this kind of virulence across the globe, in different temperature and geographical conditions, in a natural way. It is also suspicious about the origin of the particular virus, as this matches all the behaviour one can encounter in a manmade virus or product of a recombined host.

There are innumerable evidences stated the direct relationship between urbanization, war \& ever growing rates of infections, from the ancient times. Under the mask of sanitization, vaccination \& e.t.c. the human race is promoting and designing infection favorable polluted conditions desperately. The incidences of epidemic, pandemics and infections are always have a direct connection with the environmental pollutants, which are the gifts from the human civilization. Day by day we have done several manipulations with our environment to satisfy our superiority complexes. Whenever any voice raised in order to identify these fallacies, the materialistic community always used a degraded version of scientific enquiry to suppress the facts. The resultant is this drug-dependent diseased society.

Table 1: Shows Pandemic/ Epidemic, Association and year

\begin{tabular}{|c|c|c|c|}
\hline $\begin{array}{l}\text { Sr. } \\
\text { No. }\end{array}$ & Pandemic/ Epidemic & Association & Year \\
\hline 1 & Plague of Athens & Pelloponesian war & 430 B.C. -426 B.C. \\
\hline 2 & Influenza & Roman war & 412 B.C. \\
\hline 3 & Antonine plague & Italian war & 165 A.D. to 180 A.D. \\
\hline 4 & Plague of Justinian & War result & 541 A.D.- 542 A.D. \\
\hline 5 & Cholera pandemic & British invasion & $1817,1823,1826$ \\
\hline 6 & Flu pandemic \& its consequent infections & World war-I & 1918 \\
\hline 7 & CoVID-19 & $\begin{array}{c}\text { Series of war, pollutions, environmental destruction, chemical } \\
\text { hazards, drugs \& etc. }\end{array}$ & 2019 \\
\hline
\end{tabular}

From the above discussion, it is easily to encounter the direct relationship between the war, urbanization \& infections. It is the result of our all the misdeeds and disasters made by us. From the ancient time, microorganisms act as the natural scavenger, who are meant to digest the environmental pollutants.

COVID-19: CoVID-19 or Corona Virus Disease-2019 is a mild to severe infectious \& highly communicable disease, mainly affecting the respiratory system, but also spread to other several organs, like heart, kidney, liver e.t.c.. It is caused by a virus, named 'SARS-CoV-2' (Severe Acute Respiratory Syndrome Corona virus 2), which is transmitted chiefly by contact with infectious material (such as
Respiratory droplets), characterized by fever, sore throat, oppression of chest, shortness of breath and may progress to pneumonia, fibrosis of the lung \& respiratory failure.

This monstrous viral disease of 2019 has expanded from Wuhan throughout the China and is being exported to a growing number of countries, some of which have seen onward transmission. Notably, most cases of CoVID-19 is found in those areas of the world, which are considerably developed, higher in pollution, rich in industries and whose annual medical expenditure is comparatively higher than the others.

\section{Cause Behind Viral Modification:}

The materialistic scientific community is too much worried 
about the genomic organization of the SARS-CoV-2, because this virus is continuously changing its genomic organization which means its evolving very rapidly. But this is not at all a serious mystery. Microorganisms are one of the natural components, like humans. Their purpose is to digest and clean the impurities from the nature as well as from the diseased components of the nature. But, we human beings are continuously damaging the nature consciously \& desperately. We are responsible for the natural disequilibrium of the modern time. We have destroyed the natural harmony for our cheap benefit, as a result of which a huge amount of pollutants are accumulated within us and our surroundings. Our limited hyper materialistic biased mentality is the culprit for all these kind of one-sided harmful behaviour, we have made. We are behaving in a biphasic manner, where we are creating enormous amount of impurities, as a result of that we are becoming diseased; on the other hand, we are trying to kill microorganisms, which are important for the maintenance of the natural equilibrium.

Viruses are as similar as other members of this natural family. In this ever changing natural environment, they also have to evolve themselves, to save their life and also adaptation from their side is important for their scheduled function, i.e. cleaning of the impurities. It is neither a strange phenomenon nor very supersizing. If they have to survive, they also have to evolve to a complexes form, like the humans. The evolution of the humans is suggesting that evolutions of the today's human beings are also for the purpose for survival. So, if humans can evolved in a more complex form than their previous form for the survival then why not microorganisms. Deigning of the vaccines and ever-growing administration of them can satisfy our hyper conscious humanitarian complex mentality, but it ultimately can create confusion in the body's field. Another dangerous fault of this system is that; we are considering ourselves as god and we love to; but actually we are nothing but a minutest dust particle in respect to this creation.

The evolutions of the viruses are just qualifying Darwin's two theories, i.e.

i). Struggle for existence

ii). Survival for the fittest.

So, the viral or microorganism community is just struggling for the purpose of survival. This explanation is applicable only if the virus is naturally originated. But, there are several evidences about the artificiality of the particular virus. This virus is considered as artificial because-----

- Rate of modification is abnormally high

- It is not affected by geographical differences

- It is not affected by temperature

- It adapts very rapidly the geographical modification

- It acts through such a gateway, which is chiefly and knowingly man made

It is very obvious that, materialistic scientific community will surely deny this facts and they must be indulge themselves to prove its natural origin. They will also arrogantly argued to promote the poisonous rumor of vaccines and anti-virals in order to satisfy the pharmaceutical lords.

Risk Groups: Although peoples of diverse age group, sex, geographical distribution and occupation are readily affected by SARS-CoV-2, but among those who are in the red zone-----

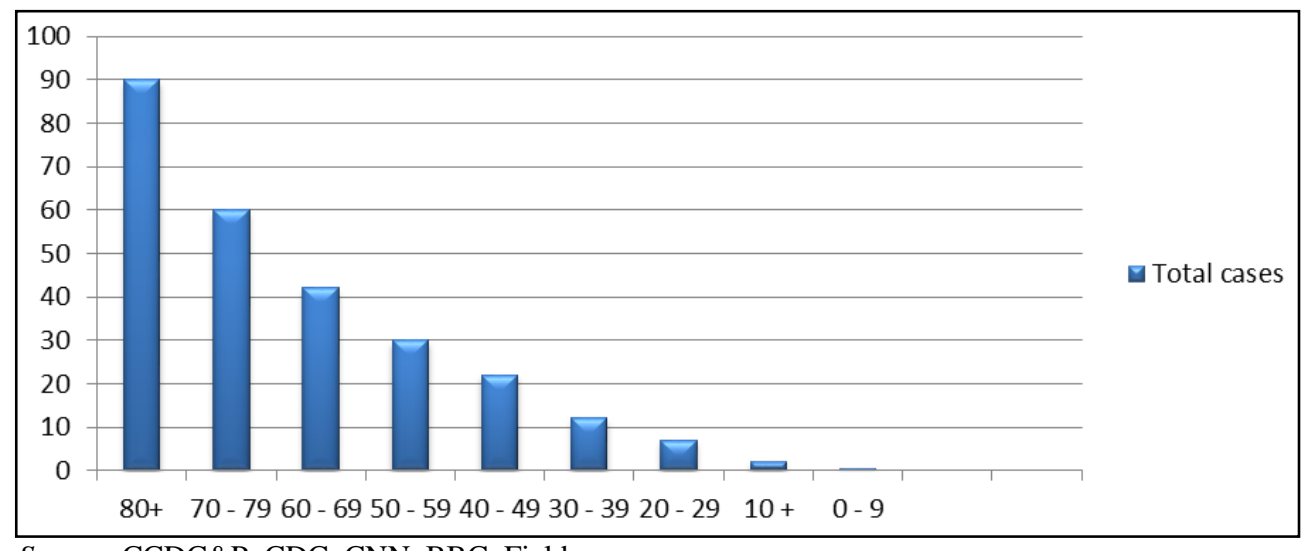

Source: CCDC\&P, CDC, CNN, BBC, Field survey

Fig 4: Total CoVID+ Cases according to age

Table 2: Shows rank, age, Co-Morbidities, gateways and cause

\begin{tabular}{|c|c|c|c|c|c|}
\hline Rank & Age & Sex & Co-Morbidities & Gateways & Cause \\
\hline 01 & $80+$ & $\begin{array}{l}\text { Male- } 82 \% \\
\text { Female- } 71 \%\end{array}$ & $\begin{array}{ll}\text { - } & \text { Cardio-vascular diseases } \\
\text { - } & \text { Metabolic diseases } \\
\text { - } & \text { Bronchial asthma } \\
\text { - } & \text { Post tubercular lung } \\
\text { - } & \text { Addiction } \\
\text { - } & \text { Prostate pathology (Male) } \\
\text { - } & \text { Carcinogenic pathologies } \\
\text { - } & \text { Renal pathology } \\
\text { - } & \text { Autoimmune Disorders } \\
\text { - } & \text { Immuno-compromization } \\
\text { - } & \text { History of HRT } \\
\end{array}$ & $\begin{array}{ll}\text { - } & \text { ACE2 } \\
\text { - } & \text { TMPRSS2 }\end{array}$ & Oxidative Stress \\
\hline
\end{tabular}




\begin{tabular}{|c|c|c|c|c|c|}
\hline & & & $\begin{array}{ll}\text { - } & \text { Psychological Disturbances } \\
\text { - } & \text { Neuro-Degenerative diseases } \\
\text { - } & \text { Endometrial pathology (Female) } \\
\text { - } & \text { Drug-abuse } \\
\text { - } & \text { Nutritional deficiency } \\
\text { - } & \text { Allergic tendency }\end{array}$ & & \\
\hline 02 & $70-79$ & $\begin{array}{ll}\text { - } & \text { Male- } 79 \% \\
\text { - } & \text { Female- } 57 \%\end{array}$ & $\begin{array}{l}\text { - } \quad \text { Cardio-vascular diseases, } \\
\text { - } \quad \text { Metabolic diseases, } \\
\text { - } \quad \text { Adonchial asthma, } \\
\text { - } \quad \text { Prostate pathology (Male) } \\
\text { - } \quad \text { Carcinogenic pathologies } \\
\text { - } \quad \text { Renal pathology } \\
\text { - } \quad \text { Psychological Disturbances } \\
\text { - } \quad \text { Neuro-degenerative Diseases } \\
\text { - } \quad \text { Immutoimmune Disorders } \\
\text { - } \quad \text { Endometrial pathology (Female) } \\
\text { - } \quad \text { Drug-abuse } \\
\text { - } \quad \text { Alleritional deficiency } \\
\text { - } \quad \text { Obesity }\end{array}$ & $\begin{array}{ll}\text { - } & \text { ACE2 } \\
\text { - } & \text { TMPRSS2 }\end{array}$ & Oxidative Stress \\
\hline 03 & $60-69$ & $\begin{array}{l}\text { - } \quad \text { Male- } 72 \% \\
-\quad \text { Female- } 52 \%\end{array}$ & $\begin{array}{l}\text { - } \quad \text { Cardio-vascular diseases, } \\
\text { - } \quad \text { Post tubercular lung } \\
\text { - } \quad \text { Metabolic diseases, } \\
\text { - } \quad \text { Bronchial asthma, } \\
\text { - } \quad \text { Prostate pathology (Male) } \\
\text { - } \quad \text { Carcinogenic pathologies } \\
\text { - } \quad \text { Renal pathology } \\
\text { - } \quad \text { Autoimmune Disorders } \\
\text { - } \quad \text { Immuno-compromization } \\
\text { - } \quad \text { Psychological disturbances } \\
\text { - } \quad \text { Neuro-degenerative diseases } \\
\text { - } \quad \text { Endress } \\
\text { - } \quad \text { Drug-abuse } \\
\text { - } \quad \text { Nutritional deficiency } \\
\text { - } \quad \text { Allergic tendency } \\
\text { - } \quad \text { Obesity }\end{array}$ & $\begin{array}{ll}- & \text { ACE2 } \\
- & \text { TMPRSS2 }\end{array}$ & Oxidative Stress \\
\hline 04 & $50-59$ & $\begin{array}{ll}\text { - } & \text { Male- } 70 \% \\
\text { - } & \text { Female- } 48 \%\end{array}$ & $\begin{array}{l}\text { - } \quad \text { Cardio-vascular diseases, } \\
\text { - } \quad \text { Metabolic diseases, } \\
\text { - } \quad \text { Bronchial asthma } \\
\text { - } \quad \text { Post-tubercular lung } \\
\text { - } \quad \text { Addiction, } \\
\text { - } \quad \text { Prostate pathology (Male) } \\
\text { - } \quad \text { Renal pathology } \\
\text { - } \quad \text { Autoimmune Disorders } \\
\text { - } \quad \text { Immuno-compromization } \\
\text { - } \quad \text { Psychological disturbances } \\
\text { - } \quad \text { Stress } \\
\text { - } \quad \text { Eexual disturbances } \\
\text { - } \quad \text { Drug-abuse } \\
\text { - } \quad \text { Nutritional deficiency } \\
\text { - } \quad \text { Allergic tendency } \\
\text { - } \quad \text { Obesity } \\
\end{array}$ & $\begin{array}{ll}\text { - } & \text { ACE2 } \\
\text { - } & \text { TMPRSS2 }\end{array}$ & Oxidative Stress \\
\hline 05 & $40-49$ & $\begin{array}{ll}-\quad \text { Male- } 68 \% \\
-\quad \text { Female- } 46 \%\end{array}$ & $\begin{array}{ll}\text { - } & \text { Cardio-vascular diseases } \\
\text { - } & \text { Metabolic diseases } \\
\text { - } & \text { Bronchial asthma } \\
\text { - } & \text { Addiction } \\
\text { - } & \text { Post tubercular lung } \\
\text { - } & \text { Prostate pathology (Male) } \\
\text { - } & \text { Carcinogenic pathologies } \\
\text { - } & \text { Renal pathology }\end{array}$ & $\begin{array}{ll}\text { - } & \text { ACE2 } \\
\text { - } & \text { TMPRSS2 }\end{array}$ & Oxidative Stress \\
\hline
\end{tabular}




\begin{tabular}{|c|c|c|c|c|c|}
\hline & & & $\begin{array}{ll}\text { - } & \text { Autoimmune Disorders } \\
\text { - } & \text { Immuno-compromization } \\
\text { - } & \text { Psychological disturbances } \\
\text { - } & \text { Stress } \\
\text { - } & \text { Sexual disturbances } \\
\text { - } & \text { Endometrial pathology (Female) } \\
\text { - } & \text { Drug-abuse } \\
\text { - } & \text { Nutritional deficiency } \\
\text { - } & \text { Allergic tendency } \\
\text { - } & \text { Obesity } \\
\end{array}$ & & \\
\hline 06 & $30-39$ & $\begin{array}{l} \\
\\
\\
\text { - } \quad \text { Male- } \\
32 \% \\
\text { - Female- } \\
15 \%\end{array}$ & $\begin{array}{ll}\text { - } & \text { Cardio-vascular diseases, } \\
\text { - } & \text { Metabolic diseases, } \\
\text { - } & \text { Bronchial asthma, } \\
\text { - } & \text { Addiction, } \\
\text { - } & \text { Prostate pathology (Male) (Rare) } \\
\text { - } & \text { Renal pathology (Rare) } \\
\text { - } & \text { Autoimmune Disorders } \\
\text { - } & \text { Immuno-compromization } \\
\text { - } & \text { Psychological disturbances } \\
\text { - } & \text { Stress } \\
\text { - } & \text { Sexual disturbances } \\
\text { - } & \text { Endometrial pathology (Female) } \\
\text { - } & \text { Nutrug-abuse } \\
\text { - } & \text { Allergic tendency } \\
\text { - } & \text { Obesity } \\
\end{array}$ & $\begin{array}{ll}\text { - } & \text { ACE2 } \\
\text { - } & \text { TMPRSS2 }\end{array}$ & Oxidative Stress \\
\hline 07 & $20-29$ & $\begin{array}{ll}\text { - } & \text { Male- } \\
09 \% \\
\text { - } \quad \text { Female- } \\
02 \%\end{array}$ & $\begin{array}{ll}\text { - } & \text { Cardio-vascular diseases (Rare) } \\
\text { - } & \text { Metabolic diseases (Rare) } \\
\text { - } & \text { Bronchial asthma } \\
\text { - } & \text { Post tubercular lung } \\
\text { - } & \text { Pddiction, } \\
\text { - } & \text { Carcinogenic pathology (Male) (Rare) } \\
\text { - } & \text { Renal pathology (Rare) } \\
\text { - } & \text { Autoimmune Disorders } \\
\text { - } & \text { Immuno-compromization } \\
\text { - } & \text { Psychological disturbances } \\
\text { - } & \text { Stress } \\
\text { - } & \text { Sexual disturbances } \\
\text { - } & \text { Drugometrial pathology (Female) (Rare) } \\
\text { - } & \text { Nutritional deficiency } \\
\text { - } & \text { Allergic tendency } \\
\text { - } & \text { Obesity } \\
\end{array}$ & - $\mathrm{ACE} 2$ & Oxidative Stress \\
\hline
\end{tabular}

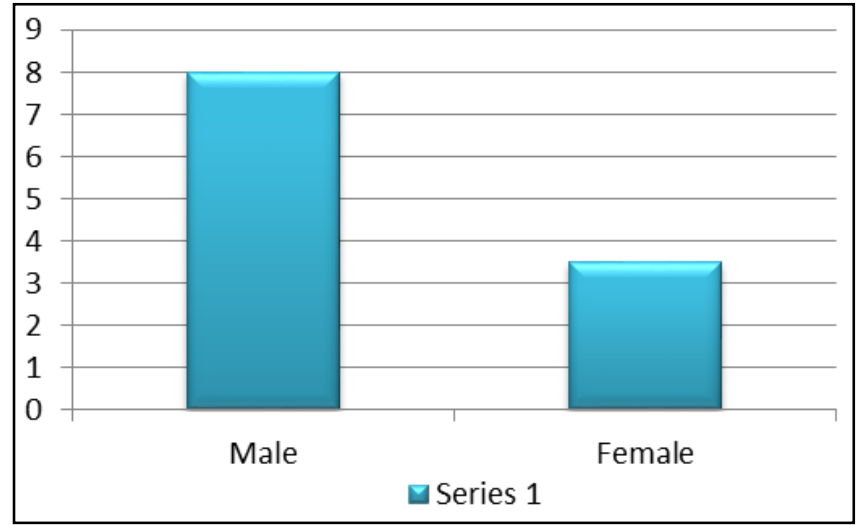

Source: CCDC\&P, CDC, CNN, BBC, Field survey

Fig 5: COVID+ cases according to Sex

From the above discussion, one can easily figure out that the cause of this viral outbreak is entirely dependent upon two gateways, which are Angiotensin- converting Enzyme- 2
(ACE-2) \& TMPRSS2, which can act as a gateway of this infection. The production of ACE2 is largely dependent upon the administration of ACE inhibitors \& Angiotensin Receptor Blockers (ARB), which are used to treat metabolic disorders and some other pathological conditions worldwide. The over expression of TMPRSS2 is common in elderly male people, as this is associated with deregulation of androgen cycle, which results into different prostate pathologies, sexual pathologies and in women this is associated with different endometrial pathologies. So, the entry points are already prepared to welcome the virus by our hyper-concerned systems and careless attitudes. One can easily make out from the above discussion; SARS-CoV-2 is just a result, not the cause of this global collapse. Before shifting to clinical features, one should take a view on oxidative stress, discussed under the heading of Aetiopathology.

Aetiopathology: The aetiological factor, which can provide a suitable environment for the virus and also which can 
make an individual prone to be affected by this virus is the 'Oxidative damage' or 'Oxidative stress', where overproduction and increased level of oxygen free radicals can be encountered. Reactive oxygen species (ROS), such as superoxide anions \& hydroxyl radical are unstable molecules that can initiate oxidation via unpaired electrons. The superoxide anion can either react with $\mathrm{NO}$, to form a highly reactive peroxynitrite molecule or be rapidly converted to hydrogen peroxide by superoxide dismutase. $\mathrm{H}_{2} \mathrm{O}_{2}$ can be converted into the damaging $\mathrm{OH}$ in the presence of $\mathrm{Fe}^{2+}$; this process is called the Fenton reaction, $\mathrm{OH}$ can also be generated from $\mathrm{O}^{-}{ }_{2}$ via the Haber-Weiss reaction. In the presence of chloride $\left(\mathrm{Cl}^{-}\right)$and bromide $\left(\mathrm{Br}^{-}\right)$ ions, $\mathrm{H}_{2} \mathrm{O}_{2}$ is catalyzed by heme peroxidases or myeloperoxidase to form hypochlorous acid $(\mathrm{HOCl})$ and hypobromous acid $(\mathrm{HOBr})$, which are very damaging oxidants. High levels of ROS have been implicated in the oxidation of proteins, lipids and DNA; this oxidation can result in tissue injury and inflammatory responses. The protein oxidation leads to dissregulation in the UbiquitinProteasome pathway, which exhibits a biphasic reaction along with suppressing the physiological apoptosis. The biphasic reaction will be inhibition of $26 \mathrm{~S} \& 20 \mathrm{~S}$ proteasome; which results into formation of highly reactive aldehydes and eventually leads to pathological apoptosis, cellular resistance and other many metabolic disorders. Along with protein oxidation, lipid peroxidation and glycoxidation will lead to oxidation of LDL, followed by pathological apoptosis, dissregulation of oxidantantioxidant mechanism, which results into cellular resistance $\&$ numerous pathological conditions.
From the incidences of CoVID-19, anyone would be able to identify the co-morbidities, encountered in the association of case fatality \& susceptibility to the viral infections. The incidences suggest that, patients with high Oxidative stress, that means who are the victims of several metabolic, neurodegenerative \& auto immune disorders are commonly affected by the SARS-CoV-2 and exhibits a drastic result. So, if one tries to find out the underlying cause of CoVID19 outbreak, that is not the SARS-CoV-2; the actual pathology behind this, is 'Oxidative stress'; SARS-CoV-2 is just a result.

From the above discussion, one can easily figure out that the cause of this viral outbreak is entirely dependent upon two gateways, which are Angiotensin- converting Enzyme- 2 (ACE-2) \& TMPRSS2, which can act as a gateway of this infection. The production of ACE2 is largely dependent upon the administration of ACE inhibitors \& Angiotensin Receptor Blockers (ARB), which are used to treat metabolic disorders and some other pathological conditions worldwide. The over expression of TMPRSS2 is common in elderly male people, as this is associated with deregulation of androgen cycle, which results into different prostate pathologies, sexual pathologies and in women this is associated with different endometrial pathologies. So, the entry points are already prepared to welcome the virus by our hyper-concerned systems and careless attitudes. One can easily make out from the above discussion; SARS-CoV-2 is just a result, not the cause of this global collapse. Before shifting to clinical features, one should take a view on oxidative stress, discussed under the heading of Aetiopathology.

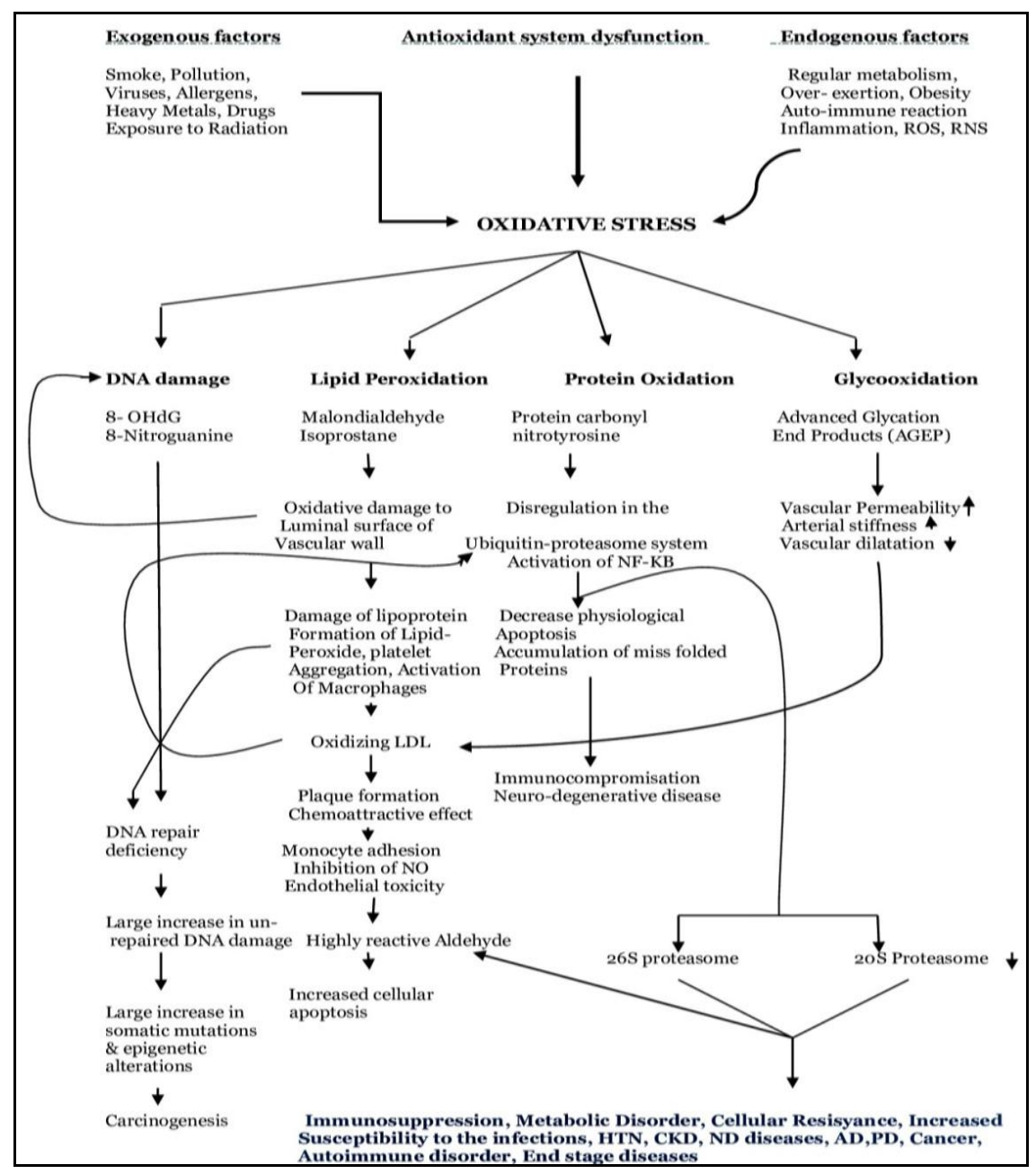


Aetiopathology: The aetiological factor, which can provide a suitable environment for the virus and also which can make an individual prone to be affected by this virus is the 'Oxidative damage' or 'Oxidative stress', where overproduction and increased level of oxygen free radicals can be encountered. Reactive oxygen species (ROS), such as superoxide anions \& hydroxyl radical are unstable molecules that can initiate oxidation via unpaired electrons. The superoxide anion can either react with $\mathrm{NO}$, to form a highly reactive peroxynitrite molecule or be rapidly converted to hydrogen peroxide by superoxide dismutase. $\mathrm{H}_{2} \mathrm{O}_{2}$ can be converted into the damaging $\mathrm{OH}$ in the presence of $\mathrm{Fe}^{2+}$; this process is called the Fenton reaction, $\mathrm{OH}$ can also be generated from $\mathrm{O}^{-{ }^{-}}$via the Haber-Weiss reaction. In the presence of chloride $\left(\mathrm{Cl}^{-}\right)$and bromide $\left(\mathrm{Br}^{-}\right)$ ions, $\mathrm{H}_{2} \mathrm{O}_{2}$ is catalyzed by heme peroxidases or myeloperoxidase to form hypochlorous acid $(\mathrm{HOCl})$ and hypobromous acid $(\mathrm{HOBr})$, which are very damaging oxidants. High levels of ROS have been implicated in the oxidation of proteins, lipids and DNA; this oxidation can result in tissue injury and inflammatory responses. The protein oxidation leads to dissregulation in the UbiquitinProteasome pathway, which exhibits a biphasic reaction along with suppressing the physiological apoptosis. The biphasic reaction will be inhibition of $26 S \& 20 S$ proteasome; which results into formation of highly reactive aldehydes and eventually leads to pathological apoptosis, cellular resistance and other many metabolic disorders.
Along with protein oxidation, lipid peroxidation and glycoxidation will lead to oxidation of LDL, followed by pathological apoptosis, dissregulation of oxidantantioxidant mechanism, which results into cellular resistance \& numerous pathological conditions.

From the incidences of CoVID-19, anyone would be able to identify the co-morbidities, encountered in the association of case fatality \& susceptibility to the viral infections. The incidences suggest that, patients with high Oxidative stress, that means who are the victims of several metabolic, neurodegenerative \& auto immune disorders are commonly affected by the SARS-CoV-2 and exhibits a drastic result. So, if one tries to find out the underlying cause of CoVID19 outbreak, that is not the SARS-CoV-2; the actual pathology behind this, is 'Oxidative stress'; SARS-CoV-2 is just a result.

From the above mentioned flowchart, it is easy to identify the unavoidable pathological relationship between oxidative stress \& viral susceptibility. Due to our extremely addiction dependent, drug-dependent, over scientific artificial lifestyle, we have adopted several attitudes, which results into the formation of oxygen free radicals in a larger amount. It should be kept in mind that, microorganisms must require a suitable environment to reside $\&$ to infect; they are the natural scavengers, attracted by the polluted environment within our body.

Now, we have to take a short view about the exogenous \& endogenous causations of productions of oxidants.

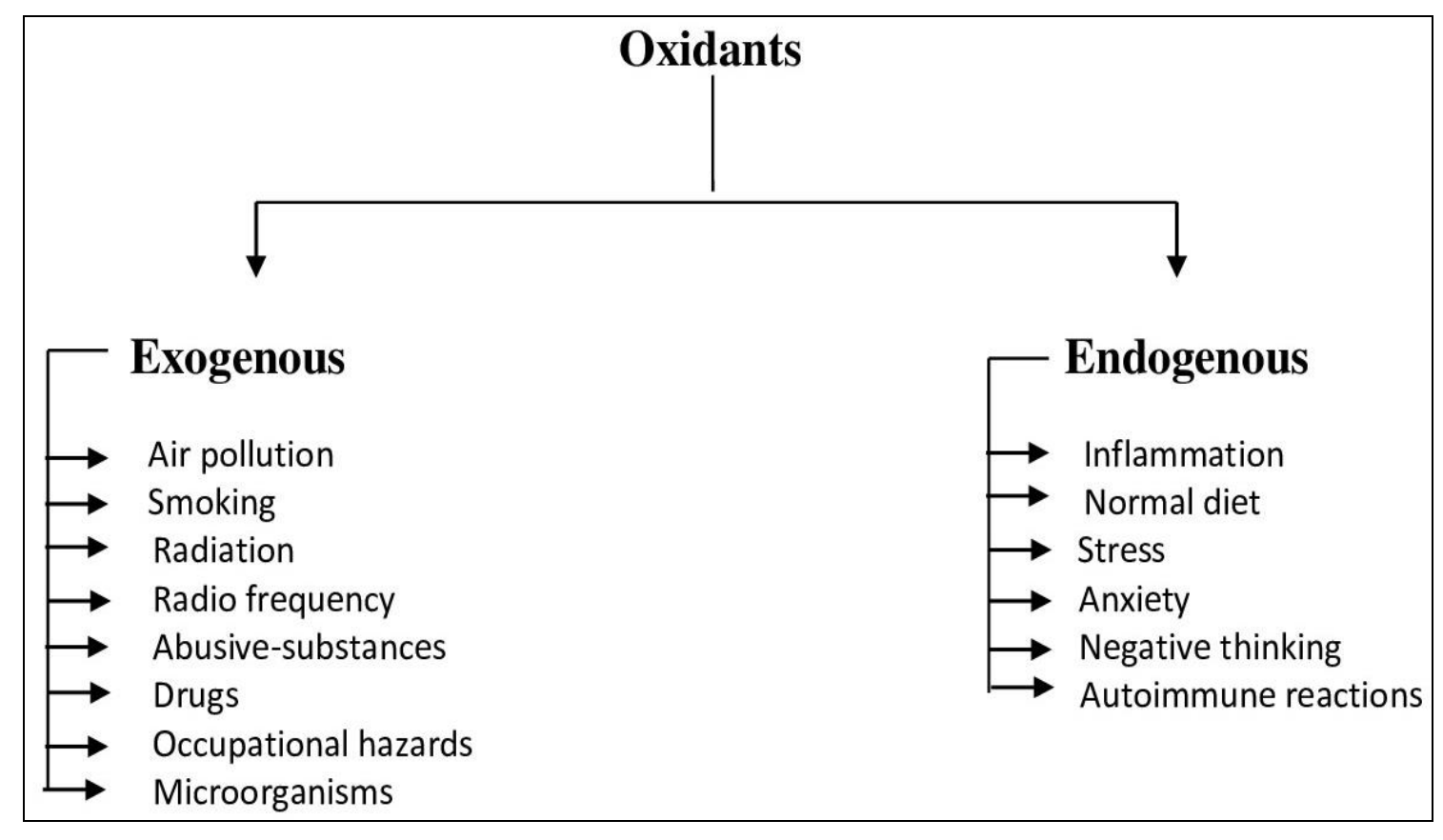

One may encounter from the incidences of CoVID-19, top affected countries are those who comes either under the category of developed countries which means having more artificial life, ingestion of more genetically modified foods, consumption of more abusive substances, exposed to more radiations, having most updated medical condition, i.e. overdependency on drugs, e.t.c.; or those countries, which are highly polluted, populated, having over drug-dependency and falls under the category of developing countries. Eventually, mostly affected countries by SARS-CoV-2 are those which have higher incidences of metabolic disorders (NIDDM, HTN, CAD), psychological disorders, Neurodegenerative disorder, obesity and several other drugdependent modernized pathologies. Top SARS-CoV-2 affected countries are those which have higher annual income from the pharmaceutical industries. 


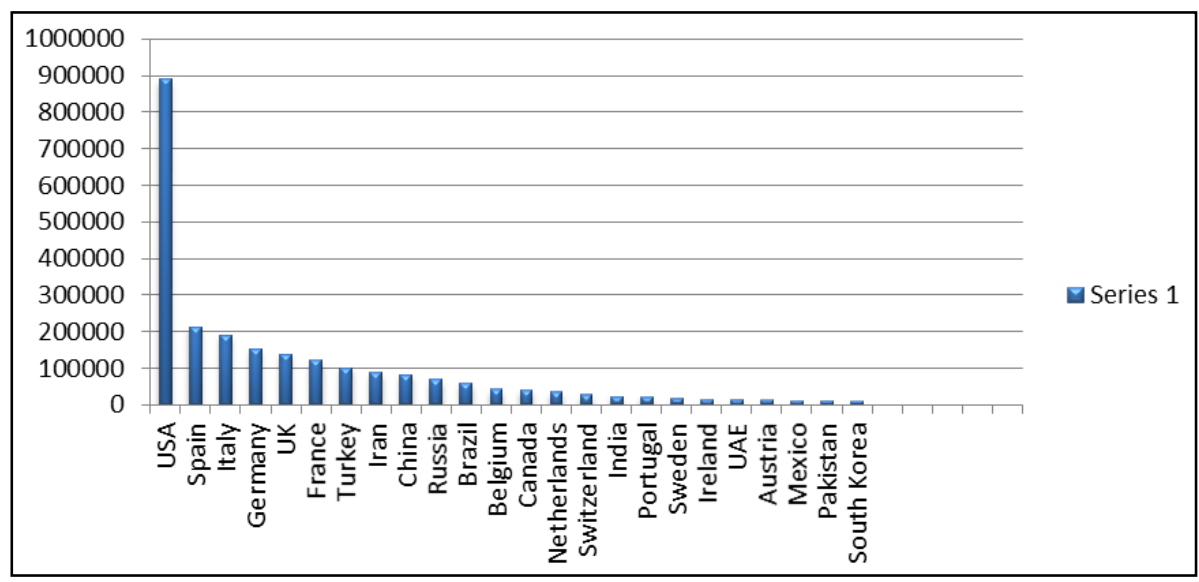

Fig 6: Highest CoVID-19 Affected Countries

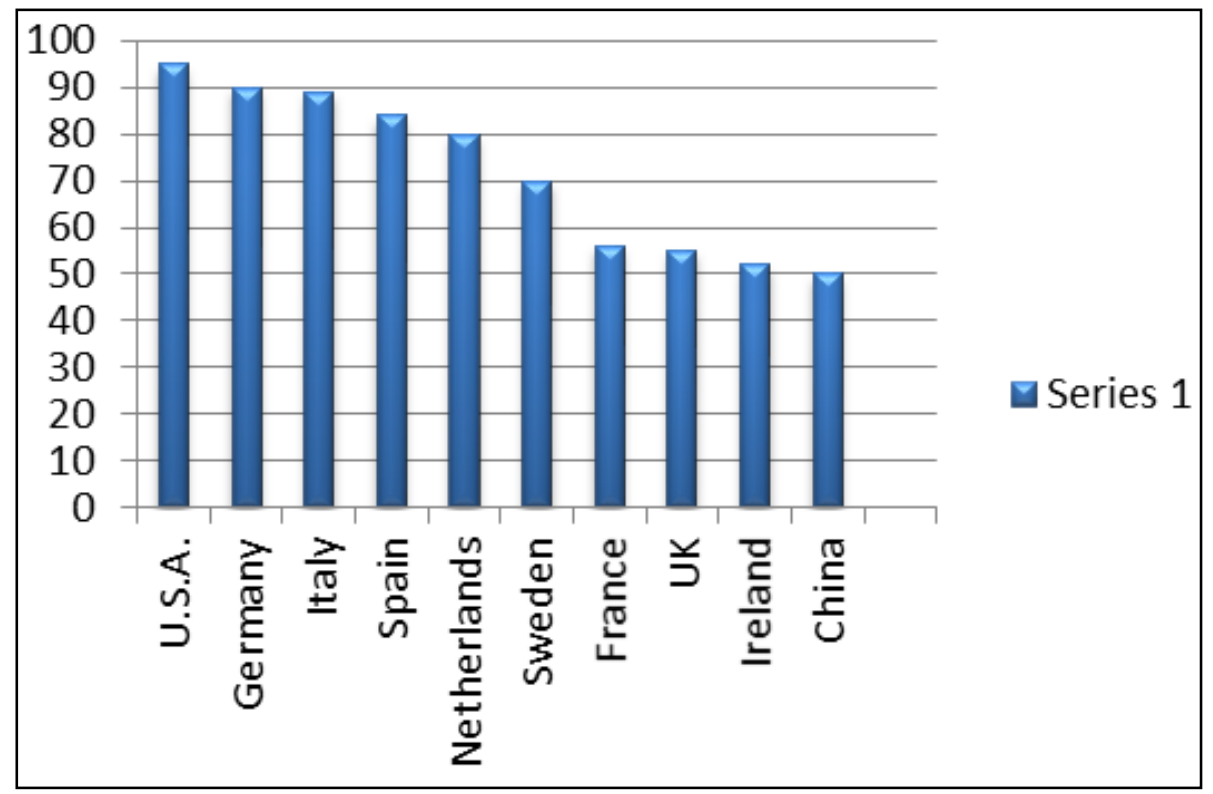

Fig 7: Most Drugs Sold Countries

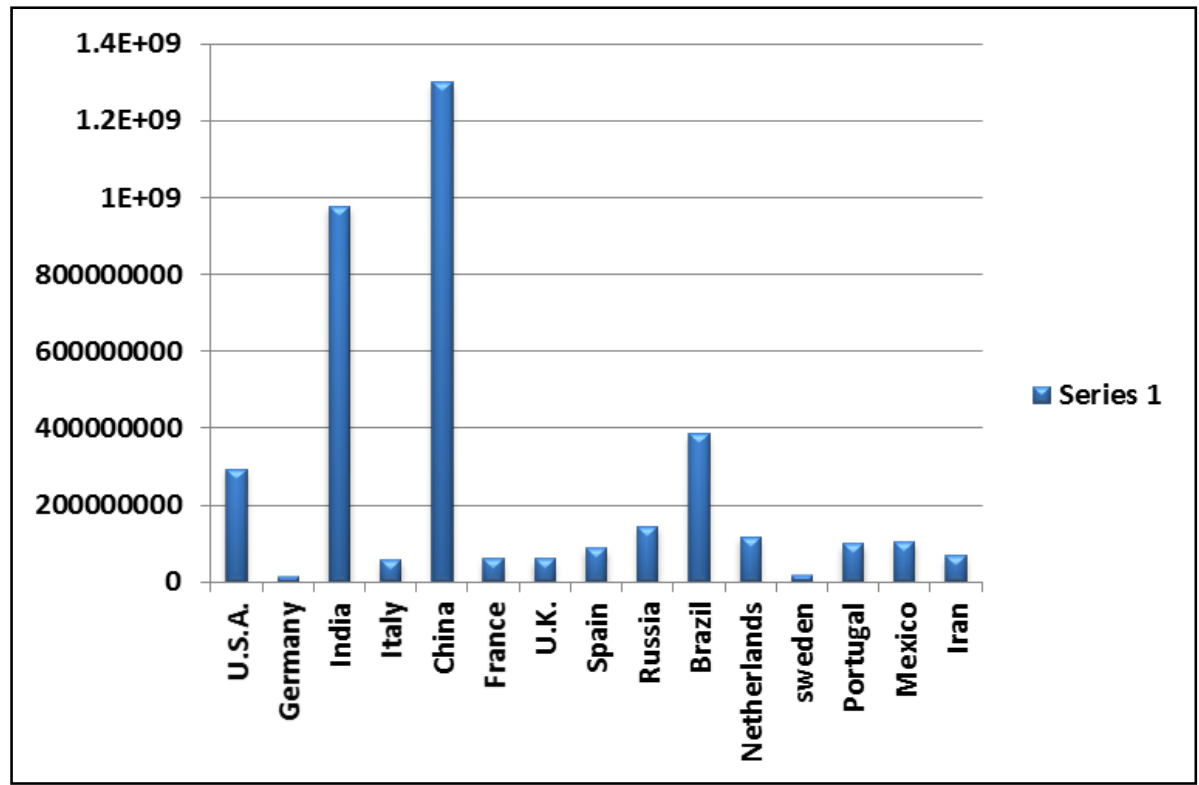

Fig 8: Countries with Higher Drug Abuse with addictions

By comparing Fig. $03 \&$ 04, one can easily understand the unavoidable relationship between CoVID-19 affected cases and drug-dependent lifestyle. Those countries having most advanced modern medical set up, whose population is largely dependent on the pharmaceutical agents, which means higher consumption of artificial chemical agents, people of those countries affected by CoVID-19 in a larger extent. Modern medical treatment is concentrating on the effects manifested through the material organism, not the cause behind that pathology. Moreover, artificial chemical 
agents can create more oxidative stress and leads to more drastic outcomes. By comparing Fig. $03 \& 05$, one can understand the further relationship between abusive substances abuse \& CoVID-19 affections. Without considering these actual pathologies, only considering a virus as a causative agent for this deadly pathology is just immaterial. Apart from these causes, one more important underlying cause is there, which is HLA- system. The persons with deficiencies or having over expression in the HLA system are more affected by CoVid-19, as incidences suggest. The irregularity of the HLA system is mediated by the above mentioned causes along with some inherited genetic defects. As a whole, the cause of this uncontrollable CoVID-19 will be.

Table 3: Shows main Cause, Sub-causes and Results

\begin{tabular}{|c|c|c|}
\hline Main Cause & Sub- Causes & $\begin{array}{r}\text { Results } \\
\end{array}$ \\
\hline Oxidative stress & $\begin{array}{c}\text { Pollution } \\
\text { Radiation } \\
\text { Drug Abuse } \\
\text { Smoking } \\
\text { Alcoholism } \\
\text { Stress } \\
\text { Anxiety } \\
\text { Radiation damage } \\
\text { Negative thinking } \\
\text { Over consumption of medicines } \\
\text { Improper treatment strategies } \\
\text { Population } \\
\text { Improper waste management } \\
\text { Genetically modified food products } \\
\text { Over use of steroids } \\
\text { Immuno-suppression }\end{array}$ & $\begin{array}{c}\text { Lung Injury } \\
\text { Redox toxicity } \\
\text { Cardio-vascular pathology } \\
\text { Neuro- degenerative diseases } \\
\text { NIDDM } \\
\text { Hypertension } \\
\text { Coronary Artery Disease } \\
\text { Dyslipidaemia } \\
\text { Obesity } \\
\text { Atherosclerosis } \\
\text { Hepatic Dysfunction } \\
\text { Psychological Disturbances } \\
\text { Auto immune disorders } \\
\text { Depression } \\
\text { Dissregulation in Oxidant- Antioxidant cycle } \\
\text { Dissregulation of RAAS } \\
\text { Dissregulation of Androgen cycle } \\
\text { Carcinogenesis }\end{array}$ \\
\hline Natural Disasters & $\begin{array}{c}\text { Cutting trees } \\
\text { Fire in Amazon } \\
\text { Fire in forests } \\
\text { Killing animals } \\
\text { Damaging natural equilibrium } \\
\end{array}$ & $\begin{array}{c}\text { Increased Pollution } \\
\text { Redox Damage } \\
\text { Carcinogenesis } \\
\text { Other Oxidative stress related diseases }\end{array}$ \\
\hline Genetic Causes & $\begin{array}{l}\text { HLA- haplotypes } \\
\text { Smoking gene } \\
\text { Cancer gene } \\
\text { Alcoholic gene }\end{array}$ & $\begin{array}{c}\text { Increased Susceptibility to infection } \\
\text { Auto immune disorder } \\
\text { More susceptible to Oxidative stress } \\
\text { Coeliac diseases } \\
\text { Metabolic disorder } \\
\text { Cancer }\end{array}$ \\
\hline
\end{tabular}

\section{Clinical Features with Staging}

Different individual exhibits variety of symptoms \& signs with different gradations. Symptoms are of varying characters, because of their varieties of affection or rather severity of affection. For the purpose of a successful prescription, one have to monitor every findings manifested on the diseased individual, including their co-morbidities, cause of that co-morbidity, duration of the co-morbidity, treatment taken for that particular disease, their food habits, life style, mode of thinking, psychological background, occupation, addictions, screen time, choice, preference \& e.t.c. Each \& every factor is important for a successful prescription, not only for the successful treatment, rather for the prevention also. From the above mentioned points, clinician can judge the degree of oxidative stress, severity of the co-morbidities and also he can calculate the complications \& severity of the present suffering. Here we have outlined some clinical findings, received from various patients of different geographical areas suffering from CoVID-19.

Table 4: Shows stages name of the stage symptoms characteristics pathological findings

\begin{tabular}{|c|c|c|c|}
\hline Stages & Name of the Stage & Symptoms & Characteristic Pathological findings \\
\hline Stage-1 & $\begin{array}{l}\text { Asymptomatic or Period of Non- } \\
\text { severe Symptoms } \\
\text { (Acute inflammatory stage) }\end{array}$ & $\begin{array}{ll}\text { - } & \text { Sneezing } \\
\text { - } & \text { Pain in throat } \\
\text { - } & \text { Constricted feeling in throat } \\
\text { - } & \text { Fever } \\
\text { - } & \text { Hyper sensitivity to the smell } \\
\text { - } & \text { Conjunctivitis } \\
\text { - } & \text { Glossitis } \\
\text { - } & \text { Oppression of chest } \\
\text { - } & \text { Shortness of breath } \\
\text { - } & \text { Irritability } \\
- & \text { General restlessness } \\
\text { - } & \text { Dry cough } \\
\text { - } & \text { Mucous in chest } \\
\text { Pain in throat }\end{array}$ & $\begin{array}{ll}\text { - } & \text { ESR } \\
\text { - } & \text { Leucocytosis } \\
\text { - } & \text { Activated T-cell }\end{array}$ \\
\hline
\end{tabular}




\begin{tabular}{|c|c|c|c|}
\hline & & $\begin{array}{ll}\text { - } & \text { Pain in Head, mainly in frontal head } \\
\text { - } & \text { Decreased appetite } \\
\text { - } & \text { Bitter taste in mouth } \\
\text { - } & \text { Hyperchlorhydria } \\
\text { - } & \text { Fearfulness } \\
\text { Ignorant about their ailment }\end{array}$ & \\
\hline $\begin{array}{l}\text { Stage - } \\
\text { II }\end{array}$ & $\begin{array}{l}\text { Period of Severe symptoms } \\
\text { (Stage of Early Chronic } \\
\text { Inflammation) }\end{array}$ & $\begin{array}{ll}\text { - } & \text { Shortness of breath } \\
\text { - } & \text { Excessive mucous on chest } \\
\text { - } & \text { Fever } \\
\text { - } & \text { Myalgia } \\
\text { - } & \text { Dyspnoea } \\
\text { - } & \text { Loss of appetite } \\
\text { - } & \text { Asomnia } \\
\text { - } & \text { Vomiting } \\
\text { - } & \text { Burning in abdomen } \\
\text { - } & \text { Irritability } \\
\text { - } & \text { Halpitation } \\
\text { - } & \text { Extreme sensitive to the cold } \\
\text { - } & \text { Headache } \\
\text { - } & \text { Irregular bowel movement } \\
\text { - } & \text { Fatigue } \\
\text { - } & \text { Palpitation } \\
\text { - } & \text { High smelling urine } \\
\text { - } & \text { Proteinuria } \\
\text { - } & \text { Haematuria } \\
\text { - } & \text { Hepatomegaly } \\
\text { - } & \text { Fearfulness } \\
\text { - } & \text { Feeling of loneliness } \\
\text { - } & \text { Escapist mentality } \\
\text { - } & \text { Forgetfulness } \\
\text { - } & \text { Tremor } \\
\end{array}$ & $\begin{array}{ll}\text { - } & \text { Lymphocytopenia } \\
\text { - } & \text { IL-6 increased } \\
\text { - } & \text { Cytokine storm } \\
\text { - } & \text { Diffuse Patchy spots in lung field }\end{array}$ \\
\hline $\begin{array}{l}\text { Stage - } \\
\text { III }\end{array}$ & $\begin{array}{l}\text { Period of extremely severe condition } \\
\text { (Stage of Chronic inflammation) }\end{array}$ & $\begin{array}{ll}\text { - } & \text { Asomnia } \\
\text { - } & \text { Metallic taste } \\
\text { - } & \text { Extreme prostration } \\
\text { - } & \text { Palpitation } \\
\text { - } & \text { Pain in chest } \\
\text { - } & \text { Dyspnoea } \\
\text { - } & \text { Extreme prostration } \\
\text { - } & \text { Constriction in chest } \\
\text { - } & \text { Heaviness of chest } \\
\text { - } & \text { Nausea } \\
\text { - } & \text { Vomiting } \\
\text { - } & \text { Diarrhoea } \\
\text { - } & \text { Gastro-Intestinal Bleeding } \\
\text { - } & \text { Bilious vomiting } \\
\text { - } & \text { Suppressed urination } \\
\text { - } & \text { Hallitosis } \\
\text { - } & \text { Haematuria } \\
\text { - } & \text { Confused } \\
\text { - } & \text { Highly anxious } \\
\text { - } & \text { Sensitive to slightest change of } \\
\text { - } & \text { surroundings } \\
\text { - } & \text { Fear of death } \\
\text { - } & \text { Panicked } \\
\text { - } & \text { Swelling } \\
\text { - } & \text { Haemorrhagic spots in skin } \\
\text { - } & \text { Anaemic condition } \\
\text { - } & \text { Bromidrosis } \\
\text { - } & \text { Delirium } \\
\text { Panicked }\end{array}$ & $\begin{array}{l}\text { - } \quad \text { Fibrotic changes is seen in the lung } \\
\text { shadow } \\
\text { Ground-Glass appearance in the Lung } \\
\text { Shadow } \\
\text { Lymphocytopenia }\end{array}$ \\
\hline
\end{tabular}




\section{Indicated Medicines according to the Stage}

Table 4: Shows Indicated Medicine

\begin{tabular}{|c|c|}
\hline Stages & Indicated Medicine \\
\hline Stage- I & $\begin{array}{ll}\text { - } & \text { Aconitum napellus } \\
\text { - } & \text { Belladona } \\
\text { - } & \text { Eupatorium perfoliatum } \\
\text { - } & \text { Gelsemium } \\
\text { - } & \text { Bryonia alba } \\
\end{array}$ \\
\hline Stage- II & $\begin{array}{ll}- & \text { Gelsemium } \\
\text { - } & \text { Bryonia alba } \\
\text { - } & \text { Hepar sulphuricum } \\
\text { - } & \text { Sulphur } \\
\end{array}$ \\
\hline Stage- III & $\begin{array}{ll}- & \text { Mercurius solubilis } \\
- & \text { Phosphorus } \\
\text { - } & \text { Arsenicum album } \\
\text { - } & \text { Chininum arsenicosum } \\
\end{array}$ \\
\hline
\end{tabular}

\section{Modus Operandi of Some Indicated Homoeopathic} Medicine:

At first, the modus operandi of Homoeopathic medicine is outlined through a flow chart. Homoeopathic medicines are rich in energy and less in materialistic quantity, which is why the chances of toxicity is minimum. The medicines are able to create similar pathway by acting through the nervous system, by conducting the impulse by means of nervous signalling. The signal first creates similar pathological condition by involving similar pathway but in the higher intensity. From the flow chart of the medicinal actions of the specific medicines of CoVID-19, one would be able to identify that; at the different levels of the natural pathological pathway, i.e. the stages of the disease several disturbances appeared naturally as a byproduct of the disease preventing mechanism of the body; the indicated medicine specific for the particular stage, neutralizes those effects by creating a similar medicinal pathway. The mechanism is not only harmless, but beneficial also. But one should keep in mind that, the proper indicated medicine must be identified in a proper manner, without any prejudice.

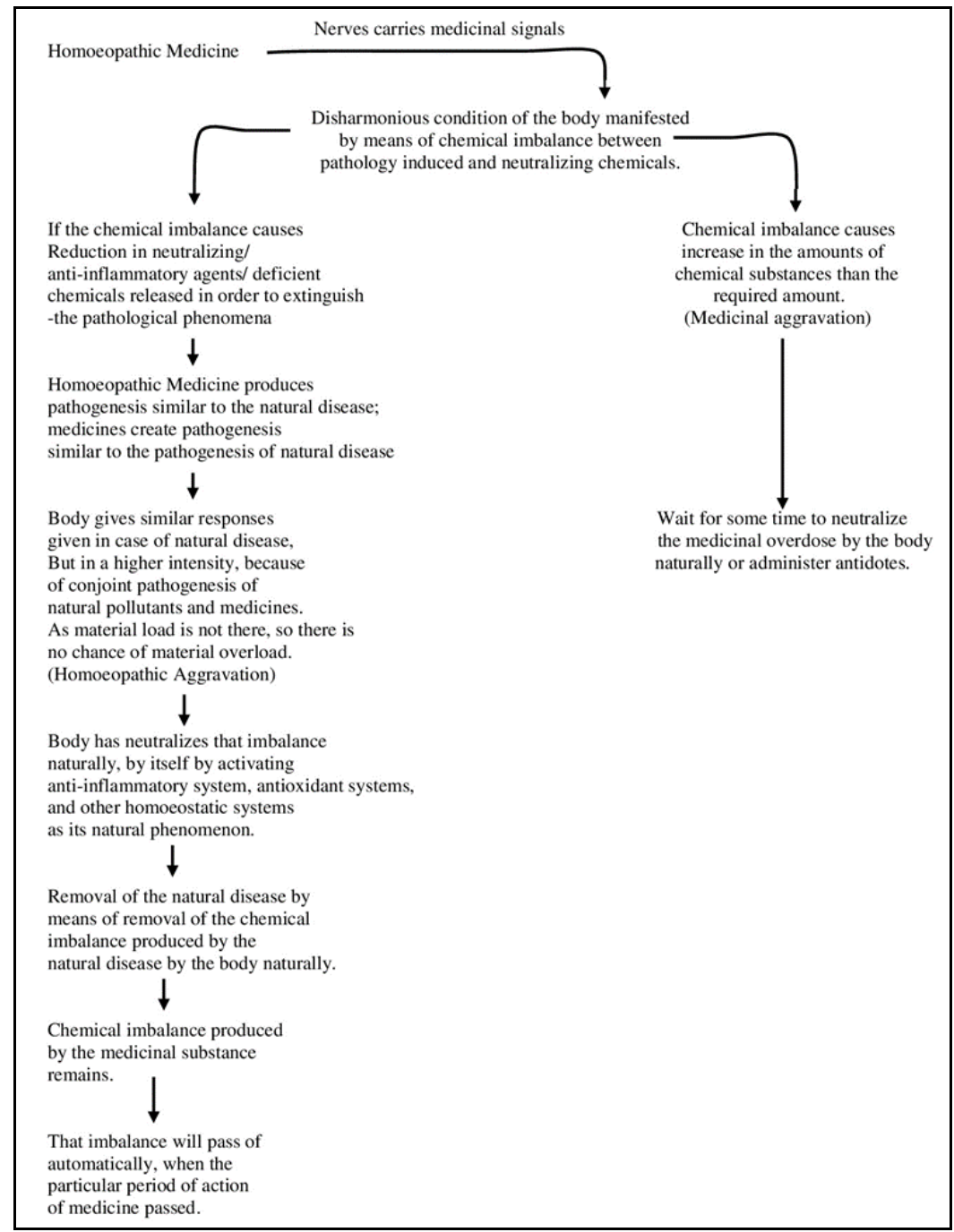




\begin{tabular}{|c|c|c|}
\hline \multicolumn{3}{|c|}{ Treatment of CoVID-19 } \\
\hline - Preventive & F Curative & Palliative \\
\hline$\rightarrow$ Proper Nutritious food & $\rightarrow$ Proper Nutritious food & $\rightarrow$ Oxygenation \\
\hline$\rightarrow$ Stop Smoking & $\rightarrow$ Stop Smoking & $\rightarrow \mathrm{F}-\mathrm{E}$ balance \\
\hline$\rightarrow$ Stop alcohol & $\rightarrow$ Stop alcohol & Ars alb./ \\
\hline$\rightarrow$ Adequate physical exercise & $\rightarrow$ Adequate physical exercise & Merc.sol. \\
\hline$\rightarrow$ Foods rich in Vit- B3 & $\rightarrow$ Foods rich in Vit- B3 & Prevention of \\
\hline$\rightarrow$ Foods rich in Vit-C & $\rightarrow$ Foods rich in Vit-C & $\rightarrow$ Hyaluronan \\
\hline$\rightarrow$ Garlic (as it is rich in Sulphur & $\rightarrow$ Garlic (as it is rich in Sulphur & formation \\
\hline Containing Allicin) & Containing Allicin) & $\Rightarrow$ Vit- $\mathrm{B}_{3} \& \mathrm{C}$ \\
\hline$\rightarrow$ Proper treatment of Co-morbidities & $\rightarrow$ Proper tratment of Co-morbidities & Other \\
\hline$\rightarrow$ Avoid negative thinking & $\rightarrow$ Avoid negative thinking & possible \\
\hline$\rightarrow$ Avoid Stress & $\rightarrow$ Avoid Stress & $\rightarrow$ moasures. \\
\hline$\rightarrow$ Management of Stress & $\rightarrow$ Management of Stress & as explained \\
\hline$\rightarrow$ Aconitum napellus on exposure & $\rightarrow$ Indicated medicine suitable & in previous \\
\hline$\rightarrow$ Maintain hygiene (Both Int. \& ext.) & for the case, with considering & curative part \\
\hline$\rightarrow$ Avoid negative promotion (In spite of & co-morbid factors & $\rightarrow$ Isolation \\
\hline degree of truth) & $\rightarrow$ Maintain hygiène (Both Int. \& ext.) & + Ventilated \\
\hline$\rightarrow$ Avoid radiation & $\rightarrow$ Avoid negative promotion (In spite of & room \\
\hline$\rightarrow$ Decrease sereen time & degree of truth) & \\
\hline$\rightarrow$ Reading of good books & $\rightarrow$ Avold radiation & \\
\hline$\rightarrow$ Maintaining of social distancing & $\rightarrow$ Maintain proper oxygenation & \\
\hline$\rightarrow$ Drug use should be minimized & $\rightarrow$ Fluid-electrolyte balance & \\
\hline$\rightarrow$ Engage yourself in productive work & should be maintained & \\
\hline$\rightarrow$ Plantation of tree is mandatory & $\rightarrow$ Isolation & \\
\hline$\rightarrow$ Stop harming animals & $\rightarrow$ Ginger \& Turmeric & \\
\hline & $\rightarrow$ Well-ventilated room & \\
\hline
\end{tabular}




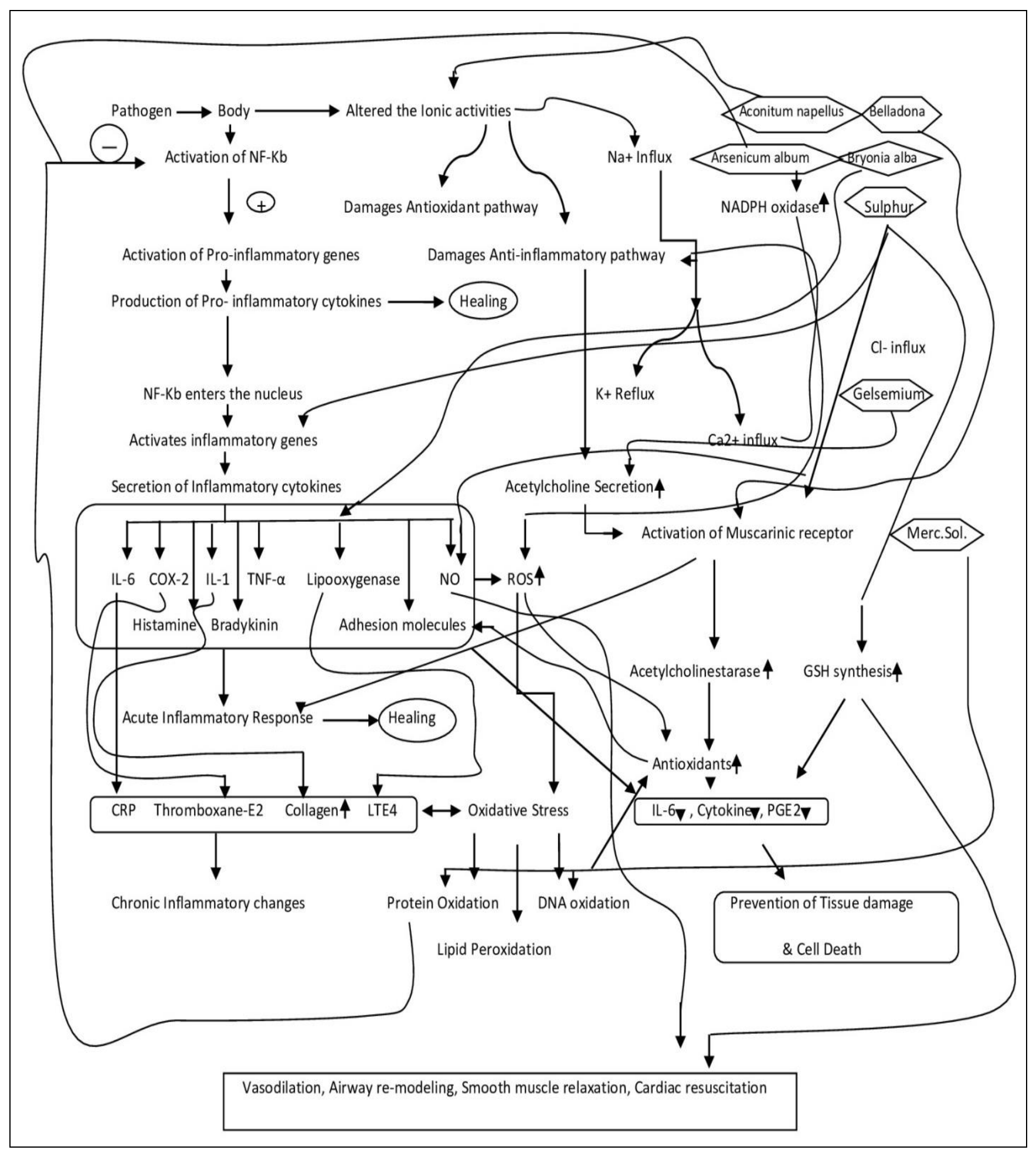

Modus operandi of Homoeopathic Medicines in CoVID-19 


\section{Treatment}

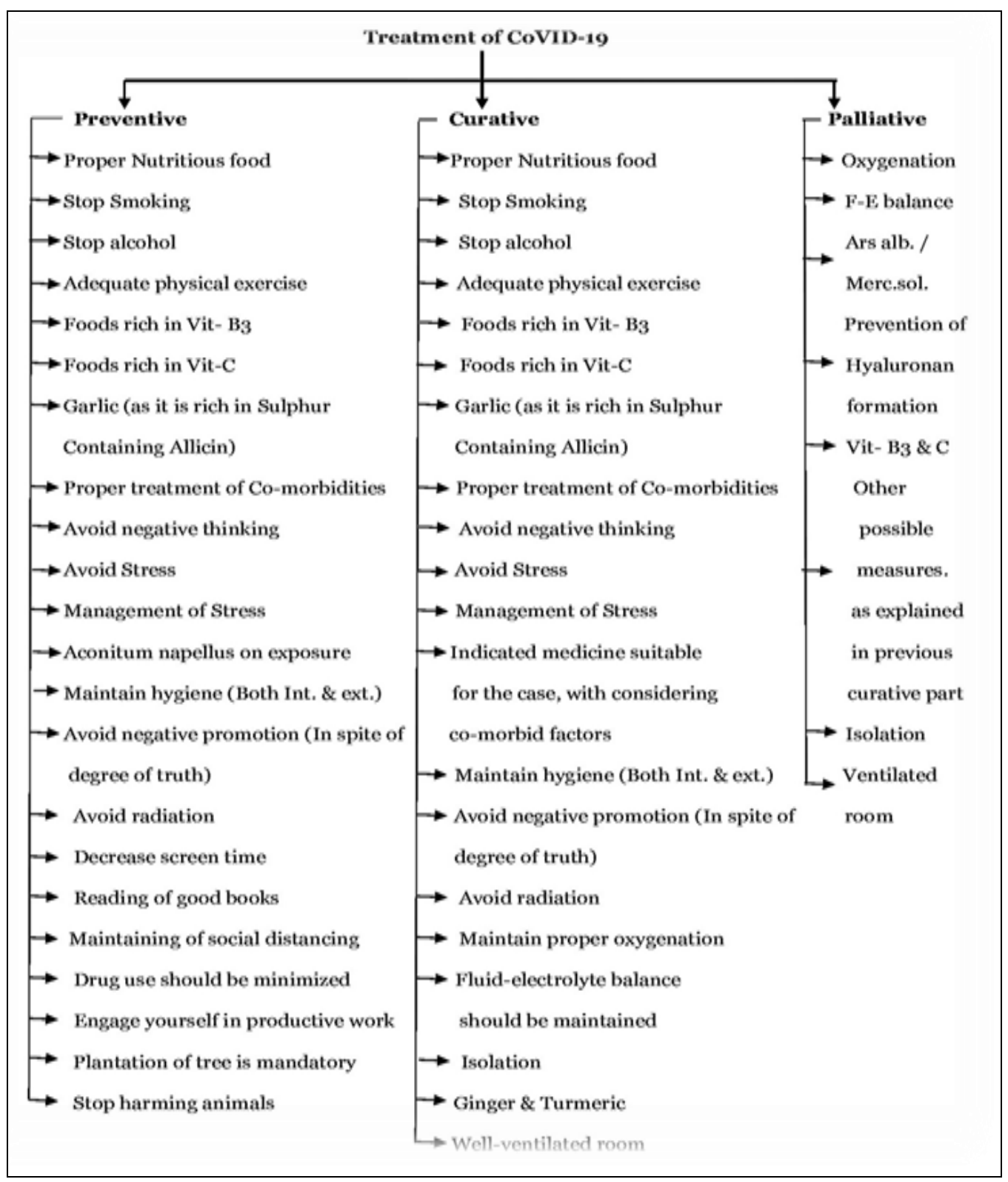

\section{Clinical Trial with Homoeopathic medications}

Clinical trial is possible in a minimum number of the patients, who are exposed to CoVID-19, who have comorbidities and also as a prophylactic. As a prophylaxis we have taken a group of volunteers, which are divided into three groups: one is on placebo, second is on Arsenicum album, irrespective of their characteristics, and third group is on the indicated medicine as per their genetic make up \& co-morbidities. Result are: $1^{\text {st }}$ group: Flu like symptom in $16 \%$ cases, 2nd group: Flu like symptoms in 5\% cases 3rd group: Absence of any flu like symptoms

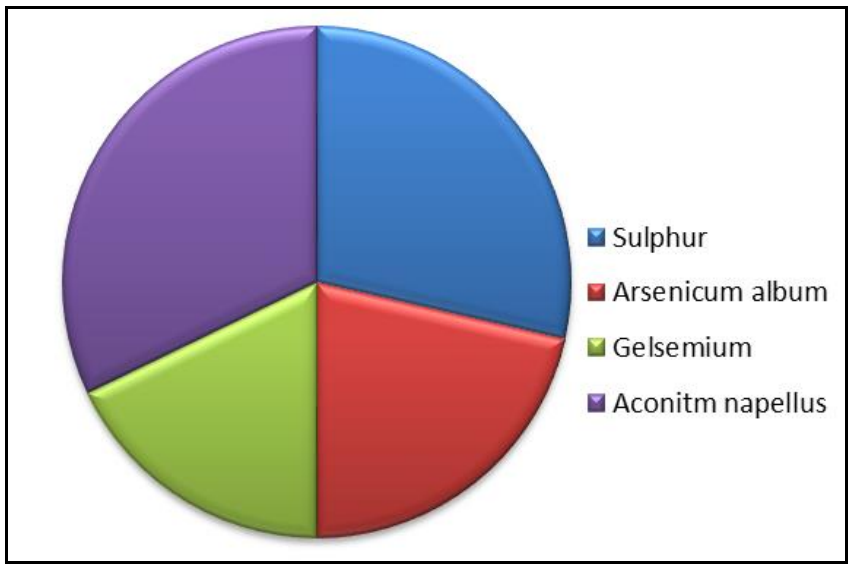

Fig 9: Prophylaxis with Homoeopathy in 3rd group 


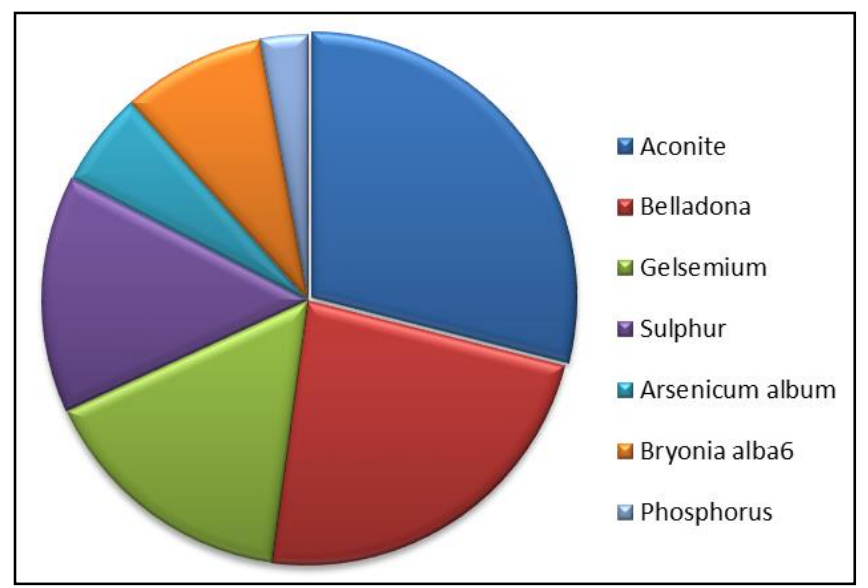

Fig 10: Flu like symptoms \& Homoeopathy

Along with the clinical trials, there are number of cases which are treated by the homoeopathic medicines successfully. Indicated Homoeopathic medicines have proved its efficacy in all the stages of the CoVID-19 in a very clear manner. There is not a single case which turns fatal during the treatment with indicated Homoeopathic medicines. It is not clear to us, why Govt. of India promoting this system of medicine as a immune booster only, particularly when there are several evidences regarding successful management with the Homoeopathic medications. We have received a few cases worldwide treated with Homoeopathic medicines \& we get our desired results.

We have noticed that, there are variations in the symptomatologies on different geographical conditions. As the virus is continuously modifying according to the geographical condition and people of different areas are of different characteristics, the manifestations are notably different. For that reason, administering an arbitrary Genus epidemicus is not at all desirable; this must be not beneficial for the mankind and for the Homoeopathic system both.

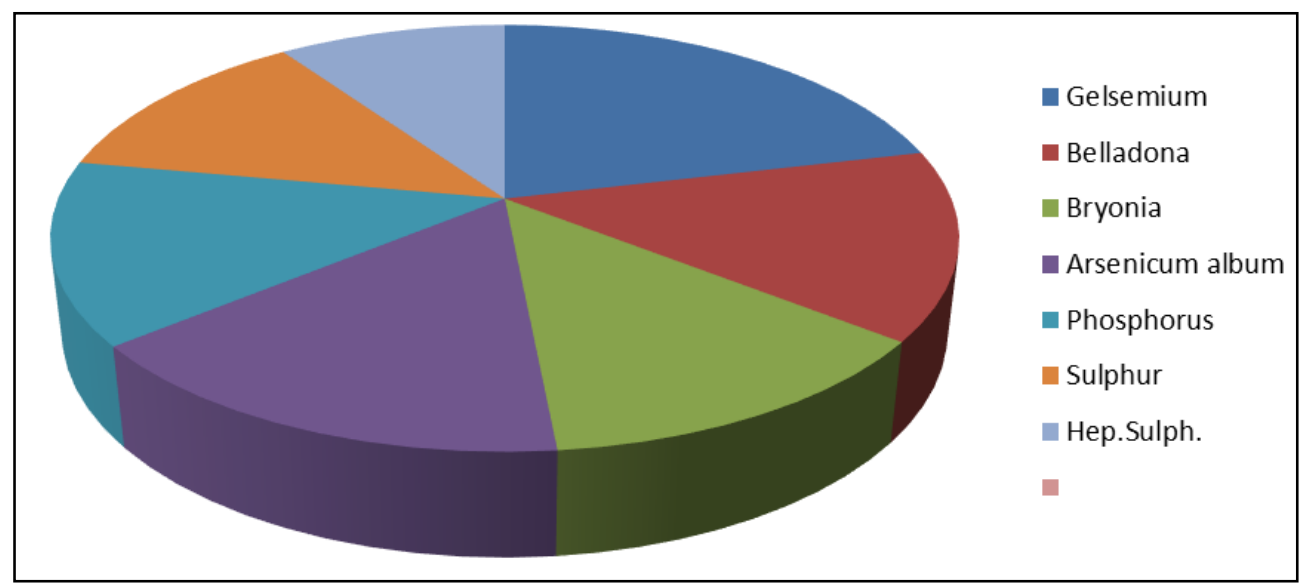

Fig 11: Mostly indicated remedies in India for CoVID +ve

\section{Conclusion}

From the above discussion one can understand all the facts, rumors \& truths of CoVID-19 \& several other pathological conditions. Faults \& fallacies are there within our psychological pattern, our life style, our understanding and above all within our treatment procedure. We are used to consider our patients as instruments and in order to correct the instrumental abnormality; we act like an engineer, without considering body's own protective functions. CoVID-19 is not at all a fatal disease, without the predisposing condition. This is the gift of our most learned scientific community, who thought themselves as the creator. Manipulation with the nature is directly proportional to this ever growing disease pillars. If we have any intention to live for a longer period in the nature, we have to manage our oxidative stress \& other internal impurities naturally. We have to live close to the nature by obeying natural rules. More we try to manipulate the nature; nature will remove us by considering us as a foreign body or diseased substance. Infections are just the result, not the cause. So, it is better to stop blaming microorganisms as a disease producing element.

"Nature is the best Physician" ---- Hippocrates

\section{Reference}

1. https://onlinelibrary.wiley.com/doi/pdf/10.1002/path.21
62

2. https://www.thelancet.com/journals/lanres/article/PIIS2 213-2600(20)30076-X/fulltext

3. Synthesis of angiotensin-converting enzyme (ACE) inhibitors: an important class of antihypertensive drugs

4. https://www.genecards.org/cgibin/carddisp.pl?gene $=$ ACE2

5. https://drbganimalpharm.blogspot.com/2010/07/meatscience-meat-and-omega-3-as-ace.html

6. https://en.wikipedia.org/wiki/Angiotensin_(1-7)

7. https://www.ncbi.nlm.nih.gov/pubmed/25019157

8. https://journals.physiology.org/doi/full/10.1152/ajpregu .00222 .2010

9. https://journals.physiology.org/doi/full/10.1152/ajpregu .00222 .2010

10. https://journals.physiology.org/doi/full/10.1152/ajpregu .00222 .2010

11. https://www.ahajournals.org/doi/full/10.1161/CIRCRE SAHA.116.307708

12. http://www.nephjc.com/news/covidace2

13. http://www.nephjc.com/news/covidace2

14. http://www.eurekaselect.com/144300/article

15. https://www.cell.com/fulltext/S0092-8674(03)00976-0

16. https://www.researchgate.net/figure/A-contemporaryview-of-the-synthesis-and-metabolism-of-angiotensinand-related-peptides_fig1_23640501 
17. https://www.ahajournals.org/doi/full/10.1161/circresaha .113 .301271

18. http://www.bioscience.org/2012/v17/af/4062/figures.ht $\mathrm{m}$

19. https://www.antibodies-online.com/ace-inhibitorpathway-pathway-18/

20. https://journals.physiology.org/doi/full/10.1152/ajpregu .00099 .2018

21. https://www.healthbeckon.com/vitamin-b3-foods/

22. https://www.explorecarttherapy.com/en/about-CAR-Ttherapy/

23. https://www.explorecarttherapy.com/en/about-CAR-Ttherapy/

24. https://www.nature.com/articles/s41418-020-0530-3

25. https://www.nature.com/articles/s41418-020-05303/figures/1

26. https://www.ncbi.nlm.nih.gov/pmc/articles/PMC26280 04/

27. https://en.wikipedia.org/wiki/Tocilizumab

28. https://ghr.nlm.nih.gov/primer/genefamily/hla

29. https://en.wikipedia.org/wiki/Human_leukocyte_antige $n$

30. https://www.ncbi.nlm.nih.gov/pmc/articles/PMC45319 $43 /$

31. https://journals.physiology.org/doi/full/10.1152/ajphear t.00217.2020

32. https://en.wikipedia.org/wiki/Immunodeficiency

33. http://www2.estrellamountain.edu/faculty/farabee/BIO BK/BioBookIMMUN.html

34. https://www.healthline.com/nutrition/garlic-fightscolds-and-flu

35. https://www.slideshare.net/HasnainRiaz3/sulphurdeficiency-and-toxicity-symptoms-in-human-body

36. https://www.atsdr.cdc.gov $/ \mathrm{mmg} / \mathrm{mmg}$.asp?id=249\&tid= 46

37. https://err.ersjournals.com/content/28/151/180063

38. https://www.labpedia.net/human-immunodeficiencyvirus-hiv-virus-aids-acquired-immunodeficiencysyndrome/

39. https://www.toppr.com/guides/chemistry/environmental -chemistry/oxides-of-sulphur-and-nitrogen/

40. https://www.toppr.com/guides/chemistry/environmental -chemistry/oxides-of-sulphur-and-nitrogen/

41. https://www.sciencedirect.com/science/article/pii/S026 9749120320601

42. https://www.toppr.com/guides/chemistry/environmental -chemistry/air-pollution/

43. https://en.wikipedia.org/wiki/Aconitine

44. https://www.ncbi.nlm.nih.gov/pmc/articles/PMC47178 90/

45. https://www.bing.com/images/search?view=detailV2\&i $\mathrm{d}=$ EFFBFA9E37381E55D07AD63A5178205B8501D3 52\&thid=OIP.ZiTV991cBjpD2YZSXJkwiwHaDU\&me diaurl=https $\% 3 \mathrm{~A} \% 2 \mathrm{~F} \% 2 \mathrm{Fmedia}$.springernature.com $\% 2$ Ffull $\% 2$ Fspringer-

static\%2Fimage\%2Fart\%253A10.1186\%252Fs12967-

017-1306-

5\%2FMediaObjects\%2F12967_2017_1306_Fig1_HTM L.gif\&exph $=352 \& \operatorname{expw}=784 \& \mathrm{q}=\mathrm{SO} 2+$ induced+lung+ damage $+\&$ selectedindex $=7 \&$ ajaxhist $=0 \& v \mathrm{t}=0 \&$ eim $=0$, $1,2,6$

46. https://en.wikipedia.org/wiki/Proteasome

47. https://en.wikipedia.org/wiki/Advanced_glycation_endproduct
48. https://www.researchgate.net/publication/259446244_F ree_Radicals_in_Cross_Talk_Between_Autophagy_and _Apoptosis

49. https://livelovefruit.com/how-a-high-protein-dietaffects-the-body/

50. https://www.academia.edu/36195358/MECHANISM OF_ACTION_OF_HOMOEOPATHIC_MEDICINE

51. https://translationalmedicine.biomedcentral.com/articles/10.1186/s12967017-1306-5

52. https://howmuch.net/articles/pharmaceutical-tradearound-the-world

53. https://en.wikipedia.org/wiki/201920_coronavirus_pandemic_by_country_and_territory

54. https://www.rightdiagnosis.com/d/drug_abuse/statscountry.htm

55. https://www.greenmatch.co.uk/blog/2018/11/mappedeuropes-most-and-least-polluted-countries

56. https://ourworldindata.org/coronavirus

57. https://commons.wikimedia.org/wiki/File:OECD_healt h_expenditure_per_capita_by_country.svg

58. https://www.lakelandtoday.ca/highlights/albertareleases-location-age-stats-for-covid-19-2180306

59. https://www.tableau.com/about/blog/2020/3/covid-19resources-data-viz-best-practices

60. https://www.medrxiv.org/content/10.1101/2020.03.22.2 0040600v1.full.pdf

61. http://pathology.ucla.edu/workfiles/Education/Transfusi on\%20Medicine/15-2-HLAReviewPartTwo.pdf

62. https://en.wikipedia.org/wiki/NF- $\mathrm{BB}$

63. http://www.functionalmedicineuniversity.com/FDMT5 41CBioInflamIG.pdf

64. http://people.upei.ca/hanna/Inflam7/Inflam-L72012.pdf

65. https://www.sciencedirect.com/topics/neuroscience/proi nflammatory-cytokine

66. https://ashpublications.org/blood/article/126/25/2724/3 4930/NADPH-oxidase-controls-neutrophilic-responseto

67. http://www.andysofia.org/viral_vs_bacterial_with_help -o/

68. https://en.wikipedia.org/wiki/Acute_respiratory_distres s_syndrome\#Diagnosis

69. https://onlinelibrary.wiley.com/doi/10.1111/apt.15731

70. https://evolution.berkeley.edu/evolibrary/news/071201_ adenovirus

71. https://www.cam.ac.uk/research/news/what-darwindidnt-know-viruses-and-evolution

72. https://phys.org/news/2016-07-viruses-revealed-majordriver-human.html

73. https://evolution.berkeley.edu/evolibrary/news/071201_ adenovirus

74. https://en.m.wikipedia.org/wiki/NF-\%CE\%BAB

75. https://www.hindawi.com/journals/omcl/2017/7028583/

76. https://www.ncbi.nlm.nih.gov/pmc/articles/PMC57529 $80 / \# !$ po $=2.83019$

77. https://jamanetwork.com/journals/jama/articleabstract $/ 218410$

78. https://www.ncbi.nlm.nih.gov/books/NBK499935/

79. https://www.medscape.com/answers/1175560104099/what-is-the-pathophysiology-of-mercurytoxicity\#qna

80. https://fdocuments.in/download/the-limiting-role-ofmucus-in-drug-absorption-drug-permeation-through- 
mucus

81. https://pubmed.ncbi.nlm.nih.gov/1055742/

82. https://pubmed.ncbi.nlm.nih.gov/1055742/

83. https://www.sciencedirect.com/topics/agricultural-andbiological-sciences/mucus

84. https://www.ncbi.nlm.nih.gov/pmc/articles/PMC31836 $30 /$

85. https://www.google.com/search?q=arsenic+poisoning+ pathogenesis\&oq=arsenic+poisoning+pathogenesis\&aq $\mathrm{s}=$ chrome..69i57j013.9570j0j7\&client=ms-androidxiaomi\&sourceid $=$ chrome- mobile $\&$ ie $=U T F-8$

86. https://www.ncbi.nlm.nih.gov/pmc/articles/PMC56602 $38 /$

87. https://www.sciencedirect.com/science/article/pii/S097 5947616305046

88. https://www.ncbi.nlm.nih.gov/pmc/articles/PMC58670 09/

89. https://www.academia.edu/21376033/Hypophosphatem ia_in_course_of_chronic_obstructive_pulmonary_disea se._Prevalence_mechanisms_and_relationships_with_s keletal_muscle_phosphorus_content

90. https://pubmed.ncbi.nlm.nih.gov/2108845/

91. https://en.m.wikipedia.org/wiki/Inhibitor_of_apoptosis

92. https://pubmed.ncbi.nlm.nih.gov/10698969/

93. https://pubmed.ncbi.nlm.nih.gov/15279799/

94. https://www.sciencedirect.com/science/article/pii/S002 7510711000030

95. https://www.sciencedirect.com/science/article/abs/pii/S 2468202017301341

96. https://www.semanticscholar.org/paper/Oxidativestress \%2C-dysfunctional-glucose-metabolism-

Butterfield-

Halliwell/d073f90c42aa184abd88fde2907bc8bfaab99a6 4

97. https://www.nature.com/articles/s41583-019-0132-6

98. https://pubmed.ncbi.nlm.nih.gov/16028370/

99. http://m.jbc.org/content/272/33/20313.full

100.https://scholar.google.com/scholar_lookup?author=H.\% 20Schuessler\&author $=$ K.\%20Schilling\&publication_ye ar=1984\&journal=Int.\%20J.\%20Radiat.\%20Biol.\&volu me $=45 \&$ pages $=267-281$

101.https://www.researchgate.net/publication/221925552_G luco-

Oxidation_of_Proteins_in_Etiology_of_Diabetic_Retin opathy

102.https://www.tandfonline.com/doi/abs/10.1080/0955300 8414550381

103.https://pubmed.ncbi.nlm.nih.gov/12086680/

104.https://www.intechopen.com/books/basic-principlesand-clinical-significance-of-oxidative-stress/proteinoxidation-and-redox-regulation-of-proteolysis

105.https://www.intechopen.com/books/lipidmetabolism/oxidative-stress-and-lipid-peroxidation-alipid-metabolism-dysfunction

106.https://pubmed.ncbi.nlm.nih.gov/10459507/

107.https://www.jimmunol.org/content/165/4/2271

108.https://www.google.com/search?q=neurodegenerative+ disorders+cellular+pathogenesis\&oq=neurodegenerativ e+disorders+cellular+pathogenesis\&aqs=chrome..69i57 .22491j0j7\&client=ms-android-

xiaomi\&sourceid $=$ chrome- mobile $\&$ ie $=U T F-8$

109.https://www.ncbi.nlm.nih.gov/pmc/articles/PMC28821 24/

110.https://journals.plos.org/plosone/article?id=10.1371/jou rnal.pone.0230295

111.https://www.ncbi.nlm.nih.gov/pubmed/20008184

112.https://www.ncbi.nlm.nih.gov/pmc/articles/PMC45245 06/

113.https://www.semanticscholar.org/paper/Effects-ofHMG-CoA-reductase-inhibitors-on-role-of-MasonWalter/d8221f8560eab5c3b001c2cba3d919ecb42b7e0a

114.https://www.webmd.com/hypertension-high-bloodpressure/guide/treatment-ace-inhibitors

115.https://www.ncbi.nlm.nih.gov/pmc/articles/PMC50482 $32 /$

116.https://pubmed.ncbi.nlm.nih.gov/8994434/

117.https://pubmed.ncbi.nlm.nih.gov/11882617/

118.https://pubmed.ncbi.nlm.nih.gov/24004508/

119.https://ehp.niehs.nih.gov/doi/abs/10.1289/ehp.8140181

120.https://www.ncbi.nlm.nih.gov/pmc/articles/PMC41760 $07 / \# !$ po $=8.79630$

121.https://www.sciencedirect.com/science/article/pii/S230 5050013601359

122.https://www.ncbi.nlm.nih.gov/pmc/articles/PMC41865 $52 /$

123.https://www.ncbi.nlm.nih.gov/pmc/articles/PMC32499 $20 /$

124.https://www.nejm.org/coronavirus

125.https://www.scribd.com/document/435632466/ICTVRiboviria

126.https://academic.oup.com/ve/article/3/1/vex012/386640 7

127.https://www.ncbi.nlm.nih.gov/pmc/articles/PMC57441 $39 /$

128.https://www.vithoulkas.com/learning-tools/books$\mathrm{gv} / \mathrm{materia-medica-volume-1/aconitum-napellus}$

129.https://www.aacc.org/community/divisions/tdm-andtoxicology/toxin-library/monkshood

130.https://pubmed.ncbi.nlm.nih.gov/19514874/

131.https://www.jcdr.net/article_fulltext.asp?id=199\#fr7

132.https://www.google.com/amp/s/www.esquire.com/news -politics/amp32030330/coronavirus-sense-of-smellcovid-19/

133.https://www.eurekalert.org/pub_releases/2020-04/wpiwrp041520.php

134.https://www.bbc.com/future/article/20200326-covid19-the-impact-of-coronavirus-on-the-environment

135.https://www.bbc.co.uk/news/health-51674743

136.https://www.google.com/amp/s/www.livescience.com/a $\mathrm{mp} / 12951-10$-infectious-diseases-ebola-plagueinfluenza.html

137.https://www.usnews.com/news/bestcountries/articles/2020-03-04/why-so-many-epidemicsoriginate-in-asia-and-africa

138.https://www.ncbi.nlm.nih.gov/pmc/articles/PMC49090 $39 /$

139.https://www.google.com/amp/s/api.nationalgeographic. com/distribution/public/amp/animals/2020/03/urbanrats-search-for-food-coronavirus

140.https://www.google.com/amp/s/www.newsmedical.net/amp/news/20200415/Anosmia-(loss-ofsmell)-confirmed-as-a-clinical-feature-of-COVID19.aspx

141.https://www.globaltimes.cn/content/1185291.shtml

142.https://abcnews.go.com/Health/story?id=117310\&page $=1$

143.https://www.ncbi.nlm.nih.gov/pmc/articles/PMC57921 $81 /$ 
144.https://pubmed.ncbi.nlm.nih.gov/29687903/

145.https://journalinflammation.biomedcentral.com/articles/10.1186/1476 $-9255-3-5$

146.https://www.ncbi.nlm.nih.gov/pmc/articles/PMC26960 $75 /$

147.https://www.researchgate.net/publication/8145533_Dep olarisation_of_the_plasma_membrane_in_the_arsenic_t rioxide_AS2O3-_and_anti-CD95induced_apoptosis_in_myeloid_cells

148.https://en.m.wikipedia.org/wiki/Biological_functions_o f_nitric_oxide

149.https://academic.oup.com/carcin/article/21/10/1789/290 8709

150.https://www.ncbi.nlm.nih.gov/pmc/articles/PMC19084 $46 /$

151.https://www.sciencedirect.com/topics/neuroscience/acet ylcholinesterase

152.https://www.hindawi.com/journals/ja/2012/681258/

153.https://www.ncbi.nlm.nih.gov/pmc/articles/PMC45402 $32 /$

154.https://www.sciencedirect.com/science/article/pii/S134 7861317300269

155.https://www.researchgate.net/publication/7024507_Ana lysis_of_airway_secretions_in_a_model_of_sulfur_dio xide_induced_chronic_obstructive_pulmonary_disease COPD

156.https://www.ncbi.nlm.nih.gov/pmc/articles/PMC30342 90/

157.https://en.m.wikipedia.org/wiki/Transforming_growth_ factor_beta

158.https://academic.oup.com/jn/article/127/5/962S/472413 2

159.https://academic.oup.com/jn/article/127/5/962S/472413 2

160.https://en.m.wikipedia.org/wiki/Lipid_peroxidation

161.https://www.ncbi.nlm.nih.gov/pmc/articles/PMC32260 $76 /$

162.https://www.ncbi.nlm.nih.gov/pmc/articles/PMC41760 $07 /$

163.https://www.nature.com/articles/s41392-020-0148-4

164.https://www.nature.com/articles/s41392-020-0148-4

165.https://www.tandfonline.com/doi/figure/10.1080/22221 751.2020.1746199?scroll=top\&needAccess $=$ true

166.https://bangordailynews.com/2015/05/07/health/blogsand-columns/the-body-can-heal-itself-but-sometimes-itneeds-help/

167.https://www.ncbi.nlm.nih.gov/pmc/articles/PMC43731 48

168.https://www.jscimedcentral.com/Pathology/pathology6-1133.pdf

169.http://pediatrics.aappublications.org/content/106/6/1307

170.https://learntherisk.org/diseases/

171.https://ourworldindata.org/vaccination 